\title{
Mosquito-borne arboviruses of African origin: review of key viruses and vectors
}

\author{
Leo Braack ${ }^{1 *}$ (D, A. Paulo Gouveia de Almeida ${ }^{2,3}$, Anthony J. Cornel ${ }^{1,4}$, Robert Swanepoel ${ }^{5}$ and Christiaan de Jager $^{6}$
}

\begin{abstract}
Key aspects of 36 mosquito-borne arboviruses indigenous to Africa are summarized, including lesser or poorly-known viruses which, like Zika, may have the potential to escape current sylvatic cycling to achieve greater geographical distribution and medical importance. Major vectors are indicated as well as reservoir hosts, where known. A series of current and future risk factors is addressed. It is apparent that Africa has been the source of most of the major mosquito-borne viruses of medical importance that currently constitute serious global public health threats, but that there are several other viruses with potential for international challenge. The conclusion reached is that increased human population growth in decades ahead coupled with increased international travel and trade is likely to sustain and increase the threat of further geographical spread of current and new arboviral disease.
\end{abstract}

Keywords: Africa, Mosquito-borne arboviruses, Vector mosquitoes, Zoonoses, Global health threats

\section{Background}

Epidemics in recent years of Zika virus (ZIKV) in South and Central America [1-3] and yellow fever virus (YFV) in Africa [4] and Brazil [5-7] serve as reminders of the dramatic manner in which apparently quiescent or stable zoonoses can flare up or spread with serious international public health, social and economic consequences. These events are steadily increasing in frequency, involving pathogens which establish foothold in new geographical territories where they become endemic after initial rapid spread. Examples include yellow fever introduced to the New World from Africa in the early 1600s with subsequent major impact [8-10], dengue virus which spread as different antigenic variants from its probable Asia-Pacific origin to the Americas in the 1960s and Africa in the 1980s [11-13], chikungunya which arose in Africa to similarly invade extensive new areas in the mid-2000s [14-18], West Nile virus which caused a stir when first diagnosed in the USA in 1999 and soon spread to Canada and Central America $[19,20]$, and most recently Zika virus with an epidemic in Micronesia in 2007 [21], French Polynesia in 2013 [22] and South America in 2015 [23].

\footnotetext{
* Correspondence: leo.braack@up.ac.za

${ }^{1}$ School of Health Systems \& Public Health, University of Pretoria, Pretoria,

South Africa

Full list of author information is available at the end of the article
}

United Nations projections indicate a likely increase in global human population from current $>7$ billion people to a probable peak of around 9.6 billion in 2050 [24]. The consequences of such population increase will likely favour the spread and impact of zoonoses. Large human population increases will be associated with increasing population density which facilitates transmission of virus either directly or through vectors. There will also be increased international movement of people by way of migration, tourism or business travel thereby increasing the likelihood of more frequent dissemination of infective sources. Similarly, there will be increased global movement of cargo and trade goods facilitating the spread of vectors, increased land transformation and disruption of historical ecological processes which promotes contact between humans and infected wildlife or sylvatic vectors. Finally, increased human population will also increase breeding site and habitat formation for virus vectors such as Aedes aegypti and Aedes albopictus, especially in expanding urban environments. A disproportionately high percentage of the mosquito-borne arboviruses currently having serious public health impact at global scale is of African origin. In addition to this subset of arboviruses, there is substantial evidence by way of seroprevalence studies of a wide range of other arboviral infections which - like Zika virus in Africa historically - are circulating within immunologically-adapted indigenous 
African populations largely having little history of serious symptoms. These include Banzi [25, 26], Bwamba [27-32], Bunyamwera [29, 30, 33-35], Germiston [34, 36], Ilesha [37], Lumbo [38], Middelburg [35], Ndumu [39, 40], Ngari [41-43], Ntaya [44], O’nyong-yong [45], Pongola [29, 30, 35], Rift Valley fever [46, 47], Semliki Forest [35], Shuni [48], Simbu [35], Sindbis [35, 49], Spondweni [50, 51], Uganda S [52], Wesselsbron [29, 30, 34, 35] and Witwatersrand viruses [53]. Given the preponderance of zoonoses of African origin that have escaped previous endemic African settings to make geographical jumps to other regions through anthropogenic processes that are likely to escalate, this paper focuses on the subset of mosquito-borne arboviral zoonoses that are already known to exist in Africa, either with potential for continuing expansion of range or of which very little is known except that they infect humans or have genetic affinities which suggest they may infect humans. When entering immunologically naïve populations in new geographical settings the public health consequences are difficult to predict.

Below we provide an outline of the relevant virus groups and specific viruses that are known to have public health risk or could have public health importance in future, including the mosquito species involved in transmission or found infected with these viruses.

\section{Synoptic overview of the African mosquito-borne arbovirues of medical importance}

Mosquito-borne viruses affecting humans are concentrated in three families, the Flaviviridae (genus Flavivirus), Togaviridae (genus Alphavirus), and the Bunyaviridae (primarily genus Orthobunyavirus but with a few important outliers such as the Phlebovirus Rift Valley Fever). For the African region, the individual viruses and their categorization, together with key attributes, are summarized in Table 1. Below follows a summary overview of the virus families and the known African mosquito-borne arboviruses in those families; the arrangement is the same as in Table 1, i.e. alphabetically within family for ease of finding and not clustered into serogroups.

\section{Flaviviridae}

Phylogenetic trees suggest that Africa was the ancestral origin of all mosquito and tick-transmitted flaviviruses [54-56], probably from what were initially non-vectored mammalian viruses [55]. Flavivirus members are readily grouped into distinct clusters, namely mosquito-borne, tick-borne, and a group of non-vectored or no-known vector viruses [55-58]. Their ancient history is tied to the Old World, but in recent times their geographical spread and epidemiologies have been significantly affected by burgeoning human populations and global movements. Tick and mosquito-borne flaviviruses diverged early, with a much more rapid evolution within the mosquito-borne viruses. Ticks change hosts and have blood-meals relatively infrequently whereas mosquitoes have multiple blood-feeds off more hosts in a much shorter time span with greater movement over a landscape given their ability to fly. Mosquito-borne viruses thus have greater opportunity to mutate and spread across shorter generational spans within a greater number of hosts, thereby facilitating evolutionary diversification. Medically-important mosquito-borne flaviviruses can be sub-clustered into two groups. One group comprises viruses associated with Aedes mosquitoes several of which cause haemorrhagic disease in primates. The other group subdivided into predominantly Aedestransmitted viruses often also causing haemorrhagic symptoms, and predominantly Culex-transmitted viruses often associated with encephalitic disease [55]. Phylogenetic analyses suggest multiple introductions of arboviruses from the Old World to the New World in recent millennia and that the most parsimonious explanation for current genetic distributions indicates an "Out-of-Africa" ancestry; all of the Culex-associated flaviviruses currently circulating in Asia, Australia, Europe and the America's appear to have evolutionary roots in Africa [56]. It has also been posited that, like yellow fever virus, dengue virus similarly had its origin in Africa and was frequently transported to the America's during the slave period $[57,59]$. Other more deeply rooted ancestral lines of viruses dating back 2000 to 3000 years appear to have dispersed eastwards out of Africa and given rise to Japanese encephalitis virus, Murray Valley encephalitis virus and others [56].

\section{Banzi virus (BANV)}

Banzi virus was first isolated in 1956 from the blood of a febrile child in South Africa [25] and subsequently confirmed from a febrile patient in Tanzania [60]. Seroprevalance studies have shown BANV to be widely distributed across southern Africa including Angola, Botswana, Mozambique, Namibia and South Africa [25, 34]. BANV has been repeatedly isolated from wild-caught Culex rubinotus $[49,61]$ which is regarded as the primary vector of this virus [62]. Rodents are believed to be the natural host [63]. Culex rubinotus is widely distributed in Africa and abundant in subtropical coastal marshlands [62]. This mosquito appears to maintain a cycle of viral transfer between rodents but only infrequently feeds on humans $[61,62,64,65]$. Little else appears to be known regarding BANV.

\section{Dengue virus (DENV)}

Generally described in the literature as a virus with core distribution in Asia, the historic origin of dengue virus (DENV) remains somewhat elusive and may also have 


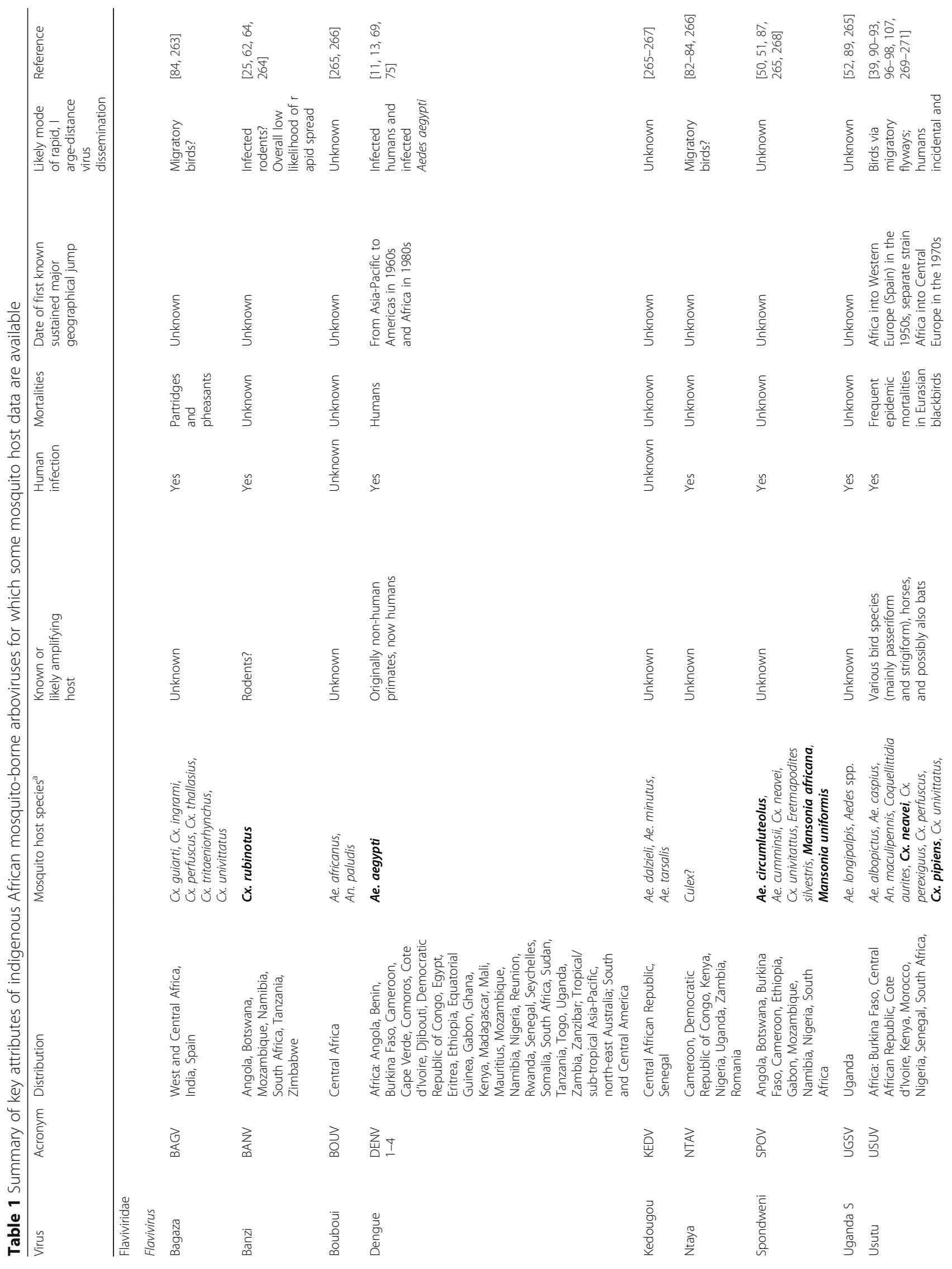




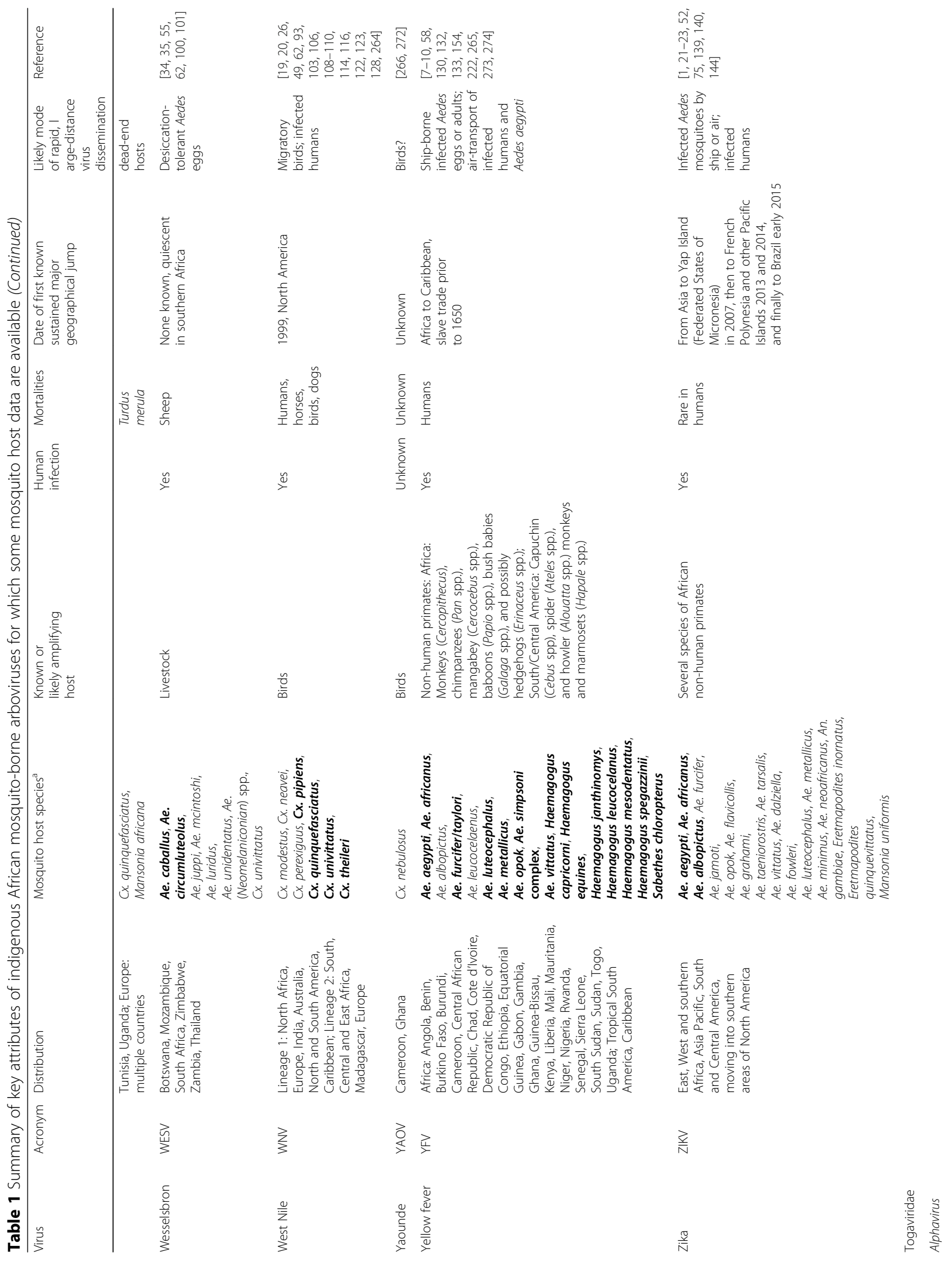




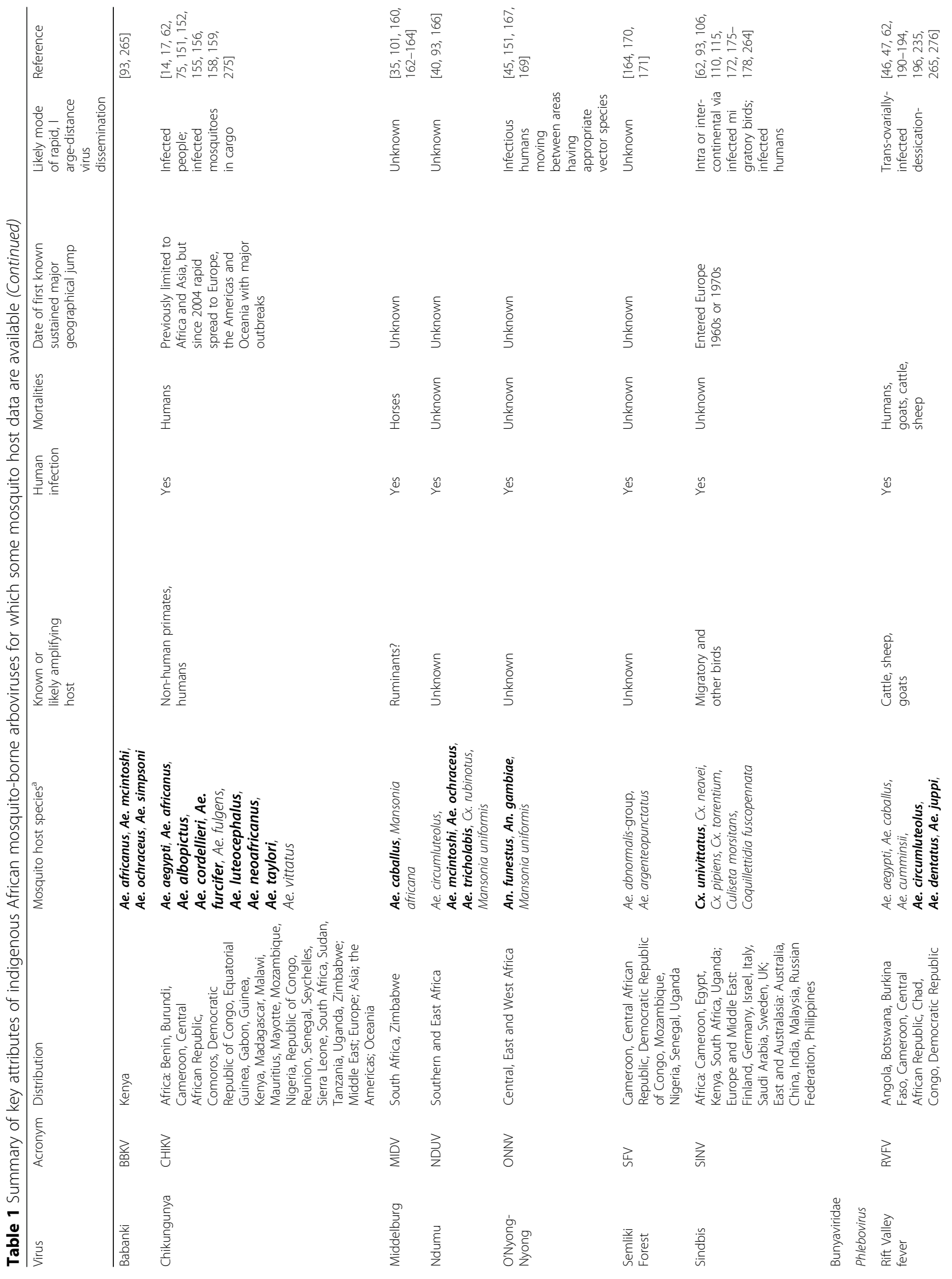




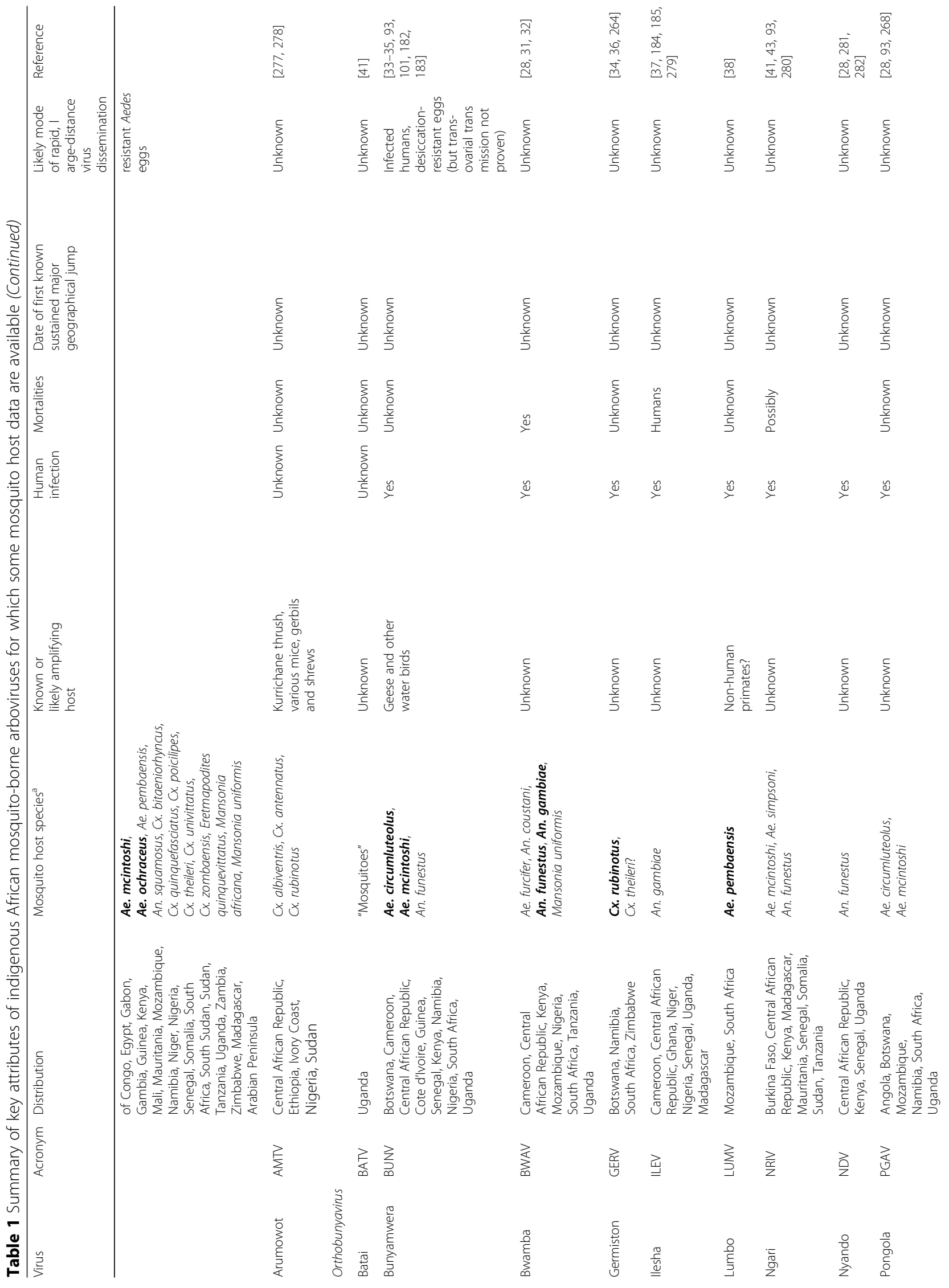




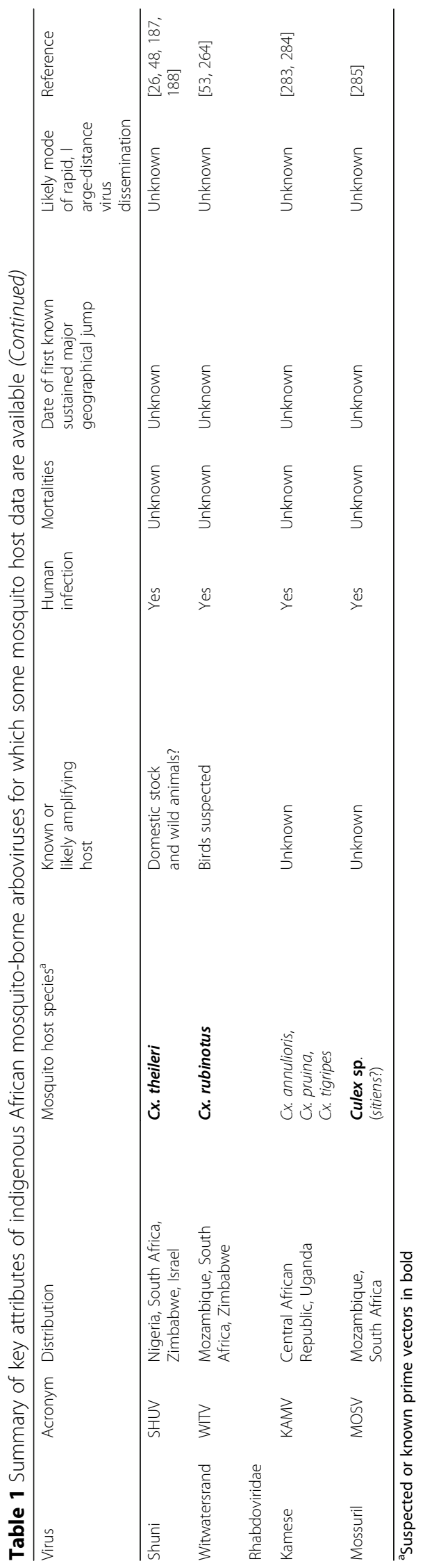


been in West Africa [57]. DENV first appeared in the America's more or less the same time as yellow fever, implying that DENV and YFV may have been transported on the same slave ships along with the historically African mosquito Aedes aegypti [55]. Whatever its historic origins, DENV was first formally described from Japan in 1943 and Hawaii in 1945, epidemics at that time being reported widely across the region from India to the Pacific Islands [13]. From the Asia-Pacific region it spread again to the Americas in the 1970s and Africa in 1984 [13], subsequently dispersing to more than 120 countries mostly in the tropics and subtropics, where it is now one of the most important infectious diseases in the world and causes serious morbidity and mortality [66-68]. DENV has been reported from 34 countries in sub-Saharan Africa [69], fully listed in Table 1. DENV is a complex of four phylogenetically and antigenically distinct serotypes causing dengue fever (DF) and dengue haemorrhagic fever (DHF) in humans. All four serotypes of DENV are believed to have evolved independently from sylvatic origins during the preceding 1 thousand years [70], with strong evidence that DENV was originally a monkey virus [57].

An estimated 50 to 100 million cases of dengue fever and 250 to 500,000 cases of dengue haemorrhagic fever (DHF) are reported throughout the world each year, mostly among young children, with case fatality rates varying from $0.5 \%$ to $5 \%$ in Asian countries [67, 68, 71-74]. Dengue causes more illness and death than any other arboviral disease acquired by humans [12]. Typical symptoms of DF include high fever, severe headache, myalgia, arthralgia, retro-orbital pain, and maculopapular rash, resulting in incapacitating disease. High fever, bleedings, intense continuous abdominal pain and persistent vomiting are associated with DHF, deteriorating to circulatory failure and altered mental status. Cases of dengue have increased in Africa over the preceding three decades, with major epidemics in West and East Africa in the 1990s and records of dengue in Angola and Mozambique [74, 75]. Dengue virus is transmitted among humans by Ae. aegypti and Ae. albopictus mosquitoes, the former being the primary vector in urban areas while Ae. albopictus is more important in peri-urban and rural environments [68, 72, 76-78]. In addition to the endemic and epidemic cycles in urban and peri-urban areas involving humans as reservoir and virus-amplifying hosts, ecologically distinct sylvatic enzootic cycles are known from West Africa [79] and Southeast Asia, involving non-human primates and sylvatic Aedes mosquitoes [80].

\section{Ntaya virus (NTAV)}

Ntaya virus was first isolated from mice inoculated intracerebrally with a pool of mixed-species mosquitoes collected in Uganda in 1951 [81]. Of the 1318 mosquitoes comprising 20 species in the pool, 1284 were of the genus Culex, but the identity of the vector species remains unknown. Antibodies to NTAV indicate presence of the virus in humans from multiple West, Central and East African countries, specifically Nigeria, Cameroon, Central African Republic, Uganda and Kenya [44]. Symptomatic infection manifests with fever, rigors, myalgia, and headache [44]. Serosurveys have revealed antibodies in a variety of migratory birds and domestic animals ( $1.6 \%$ to $13.9 \%$ in sheep, cattle, goats, pigs) in Romania [82, 83]. NTAV is neurotropic in birds and causes haemorrhages in the brain, lungs, liver, heart, ovaries, and splenomegaly [84].

\section{Spondweni virus (SPOV)}

Spondweni virus was first described from virus collected in 1955 from a pool of Mansonia uniformis mosquitoes collected in the sub-tropical northern KwaZulu-Natal Province of South Africa [50, 85]. Tests for antibodies among rural people living in the area indicated very low seroprevalence, but two laboratory workers became ill with the virus after working with infected materials. In addition to the initial isolation of SPOV from M. uniformis, other mosquitoes hosting the virus subsequently collected from the same area include Mansonia africana, Aedes circumluteolus and to a lesser degree from Aedes cumminsi and Eretmapodites silvestris [50]. The majority of isolations from mosquitoes has been from Aedes circumluteolus [50, 86]. SPOV infection has been confirmed from countries widely across sub-Saharan Africa (Angola, Botswana, Burkina Faso, Cameroon, Ethiopia, Ghana, Mozambique, Namibia, Nigeria, South Africa), where patients showed symptoms of acute febrile illness including fever, chills, headache, myalgia, arthralgia, nausea, maculopapular and pruritic rash $[51,87,88]$.

\section{Uganda S virus (UGSV)}

Uganda $S$ virus was isolated from a pool of three species of Aedes mosquitoes in Uganda in 1947 [52]. High antibody titres were found in $5.8 \%$ of 121 human sera from western Uganda and in the serum of one of six wild monkeys. Laboratory infections of rhesus, grivet and red-tail monkeys failed to produce any clinical symptoms and yielded very low titre of circulating virus or complete absence [52]. Another study indicated that under experimental conditions the virus could be maintained in Ae. aegypti for up to 79 days and that these mosquitoes appear to be efficient vectors of the virus capable of transmission after an incubation period of less than 10 days [89].

\section{Usutu virus (USUV)}

Usutu virus was first isolated from mosquitoes in South Africa in 1959 [60]. Recent genetic analysis suggests 
there are at least six distinct lineages of USUV, the earliest possibly deriving from southern Africa going back to at least the beginning of the sixteenth century [90]. USUV now occurs widely dispersed in Africa reaching from Morocco through to South Africa [91]. USUV has been repeatedly introduced into Europe over the past 50 years, migratory birds using defined flyways being the most likely agent [90]. Using virus phylogenetic relationships and geographical distributions and overlapping this with known migratory bird flyways suggests three primary routes whereby USUV likely spread into and across Europe: an east Atlantic pathway linking Africa with western Europe (Spain), a Black Sea/Mediterranean pathway to central Europe, and an East Africa/West Asian pathway. The current range of virus distribution in Europe suggests an initial introduction into western Europe (Spain) in the 1950s, followed by introduction of a separate strain into central Europe in the 1970s [90]. The virus causes large-scale die-off among Eurasian blackbirds (Turdus merula) in Europe, but USUV has also been found in at least 29 other species of birds covering several families and including species known to undertake long-range inter-continental migrations such as storks, kestrels and swallows [92]. Human infections have been diagnosed from Africa and Europe, with symptoms including fever and rash but sometimes also jaundice and severe neurological impairments [93-95]. USUV has been isolated from numerous mosquito species but vector competence remains poorly understood [96]. The 1959 isolation of USUV in South Africa was from Culex neavei [60], with subsequent extractions from Culex pipiens in Kenya [93], Aedes albopictus, Aedes caspius, Culex perexiguus and $C x$. pipiens in Europe [96], and Culex perfuscus, Coquellittidia aurites and Mansonia africana in Senegal [97]. Culex neavei, from which numerous isolations of USUV have been made, occurs widespread across Africa and has strong ornithophilic feeding behaviour with high vector competence indices and is abundant at tree-top level where birds rest, which suggests it is an important vector in Africa [96]. In Europe $C x$. pipiens is considered to be the most important vector [92]. It appears that the virus is transmitted and maintained in a sylvatic cycle that involves mainly Culex mosquitoes and birds as the main amplifying hosts, humans being occasional incidental and deadend hosts; USUV has also been found in bats in Germany [90, 98].

\section{Wesselsbron virus (WESV)}

Wesselsbron virus was first isolated in 1955 as the aetiological agent responsible for abortion and high mortality among sheep during outbreaks in South Africa [99]. The virus or antibodies to it was subsequently found to be common in humans across much of the tropical eastern coastal lowland of Mozambique, Botswana [34] and northern South Africa [35, 62] as well as in cattle, sheep and goats across the same region and extending into Zimbabwe and Zambia [62, 100, 101]. Gould et al. [55] indicate that WESV is also present in Thailand. Various Aedes species have been confirmed to be involved in epizootic transmission of the virus, namely Aedes caballus, Ae. juppi, Ae. mcintoshi, Ae. luridus and Ae. unidentatus on the temperate South African Highveld plateau while Ae. circumluteolus is likely the main vector in the low-lying coastal areas of northern South Africa and in Mozambique. These mosquitoes are floodwater-breeding species, with eggs adapted to survive long dry spells, and the possibility therefore exists that vertical transovarial transmission of virus may occur between successive generations of mosquitoes [62]. Other wild-caught mosquitoes found to be infected with WESV include Mansonia uniformis, Culex univittatus and pools of mixed Aedes (Neomelaniconian) species [100].

\section{West Nile virus (WNV)}

West Nile virus was isolated and described from blood of a febrile patient in Uganda in 1937 [102]. The disease occurs widespread throughout virtually all countries in Africa from Egypt to South Africa, and also the Middle East, southern Europe, Asia, Australia and the Caribbean, North, Central and South America [20, 103-106]. Phylogenetic trees constructed from a wide range of WNV isolates suggest that WNV originated in Africa and dispersed into Mediterranean countries and Europe, from there radiating out to its current distribution [55]. It is now considered the most important causative agent of viral encephalitis worldwide [104]. Infrequent outbreaks of mild febrile disease have occurred in France, India, Israel, Egypt and South Africa since the 1950s but the frequency, severity and geographical range has increased since the mid1990s [104]. The scale of outbreaks can be very large, as demonstrated by an outbreak in 1974 which involved tens of thousands of human cases over an area of approximately $2500 \mathrm{~km}^{2}$ in the Karoo region and Northern Cape Province of South Africa. Following the outbreak, mean antibody prevalence averaged 55\% among humans but rose to $85 \%$ in some locations, while antibodies were detected in $53 \%$ of wild birds examined $[26,61]$. WNV was accidentally introduced into New York in 1999 where it caused 62 cases of human encephalitis and 7 deaths. It subsequently spread across the continental USA, Canada, Mexico, Colombia and the Caribbean [19, 105]. In the USA, where WNV is now endemic, a cumulative total of 17,463 cases of neuroinvasive disease and 1668 fatalities were attributed to WNV between 1999 and 2013 [107].

Multiple genetic lineages of WNV are recognized, of which lineages 1, 2 and 5 have been associated with 
outbreaks in humans [104]. Lineage 1 is the dominant form and occurs in North Africa, the Middle East, Europe, India, the Americas and Australia [20, 103, 104, $108,109]$. Two sub-lineages are recognized, most within one sub-lineage and the other often referred to as Kunjin virus which has only been found in Australia $[104,108]$. Lineage 2 was previously considered to be a purely Central/Southern Africa and Madagascan zoonosis $[108,110,111]$, but since 2004 has been confirmed at several sites in Europe [20, 111, 112]. Lineage 5 was designated as a distinct separate form associated with 13 human cases in India occurring between 1955 and 1982 [113]. In humans, most WNV infections are asymptomatic but often manifest as febrile illness with headache, rash, fatigue, myalgia and arthralgia; severe infections may lead to paralysis, seizures or cerebellar ataxia with associated long-term cognitive and neurological impairment $[107,114]$, and a mortality rate close to $10 \%$ among patients with neuroinvasive disease [19]. Human fatalities are mostly associated with young children and elderly patients [115]. Other vertebrates are also susceptible: a large epizootic of WNV encephalitis occurred among equines in the USA in 2002, with 14,571 cases reported and a case-fatality rate approaching 30\% [105]. In southern Africa, WNV is frequently diagnosed among horses, often causing neurologic disease and sometimes fatalities [106, 109, 116]. Similar WNV infection and deaths have been reported among horses in Italy [117] as well as horses and donkeys in France with up to 34\% mortality among those displaying neurologic symptoms [118]. WNV-associated mortality - sometimes very high - has also frequently been recorded among bird populations in multiple countries [19, 105, 107, 119-122]. WNV uses a wide range of bird species as amplifying hosts and is transmitted by various Culex mosquitoes, including the widespread $C x$. pipiens and $C x$. quinquefasciatus $[108,123,124]$. In southern Africa the principle vector is $C x$. univittatus, with $C x$. theileri as a minor vector. In Europe the principal vector is $C x$. pipiens [20, $108,125]$, while in the USA the three species $C x$. pipiens, $C x$ quinquefasciatus and $C x$. tarsalis are primary vectors dominating in different parts of the mainland USA $[104,126,127]$. Because viraemia is typically low in humans and equines, the mosquitoes get their infections from birds from where it is passed on to humans in subsequent blood-feeding. For this reason human and equine epidemics of WNV are usually associated with concurrent bird epizootics $[62,128]$.

\section{Yellow fever virus (YFV)}

Yellow fever virus originated in Africa and spread with the slave trade dating back to at least $1650[8,58,129]$. Barbados in the Caribbean was uninhabited in the early 1600 s but then heavily planted with sugarcane to satisfy burgeoning European demand. Large numbers of slaves were imported from Africa along with Ae. aegypti and YFV-infected people, subsequently infecting mainly nonimmune white overseers on the islands. Major outbreaks of YF occurred from 1647 to 1650 and again in the 1690s, driving many whites to North America where they established a new focus for YF to spread more widely across the Caribbean and South America. The impact of YFV was manifested most heavily during construction of the Panama Canal, which began in 1881 . Soon two out of every three Europeans working on the project died from either yellow fever or malaria and ultimately approximately 30,000 would die before the Canal initiative collapsed. Following the SpanishAmerican War in 1898, approximately $80 \%$ of American occupying forces in Cuba contracted yellow fever. The American Congress established a Commission headed by Walter Reed to investigate YF and in 1900 the link with Ae. aegypti was established and measures for mosquito control implemented. America took over the halfcompleted Panama Canal and finished the project in a decade, with approximately $2 \%$ of the workforce in hospital at any given time due to a combination of yellow fever and malaria [10]. YF continues to cause periodic outbreaks in Africa where it is known from 28 countries (Table 1). Epidemics can be extensive such as in Ethiopia between 1960 and 1962 estimated to have involved around 100,000 cases with 30,000 deaths, and another surge between 1984 and 1990 during which 22,647 cases were reported from Africa, of which 21,299 were from Nigeria [130]. A recent outbreak involving all 18 provinces in Angola commenced in December 2015 and by July 2016 had resulted in more than 3552 cases with 355 mortalities $[4,131]$. Typically only about $15 \%$ of persons infected with YFV develop clinical symptoms and the majority of those have mild disease and recover quickly. Usual presentations include sudden onset of fever, headache, muscle pain, backache, general weakness, red eyes, nausea and vomiting, lasting 2-4 days usually followed by uneventful recovery. However, severe disease can develop following a brief period of remission of symptoms lasting up to $24 \mathrm{~h}$ after which a second "toxic" phase sets in associated with high fever, vomiting, epigastric pains, jaundice, haemorrhagic diathesis (hematemesis), coma and death $[129,130]$. Under African sylvatic conditions YFV is transmitted primarily by Aedes africanus, Ae. furcifer/taylori, Ae. luteocephalus, Ae. metallicus, Ae. vittatus and Ae. opok [58, 130, 132, 133]. In South America a sylvatic cycle has also been established involving several Haemagogus, Aedes and Sabethes mosquitoes [58]. This sylvatic source is now the primary form of YFV infection in South America, and the disease has had no significant urban transmission in recent decades [8]. The sylvatic reservoir hosts in Africa are a range of primates 
including monkeys of the genus Cercopithecus, chimpanzees (Pan spp.), mangabey (Cercocebus spp.), baboons (Papio spp.), bush babies (Galaga spp.), and possibly hedgehogs (Erinaceus spp.), while in South and Central America the reservoir hosts involved are capuchin (Cebus spp.), spider (Ateles spp.), and howler (Alouatta spp.) monkeys and marmosets (Hapale spp.). Infected forest primates have a period of viremia lasting 1-6 days during which time they may transmit virus to mosquitoes, presumably then developing lifelong immunity. All African non-human primates except bush babies appear to be relatively tolerant to YF virus infection, in most cases developing mild symptoms but rarely leading to fatal disease. In Central and South American monkeys and marmosets, fatal infections are the rule and extermination of focal primate populations rather than development of an immune population commonly accounts for the termination of epizootics. Experimental studies have shown that Asian monkeys are very susceptible to YF virus infection, commonly developing acute and fatal disease [9]. Yellow fever is now overwhelmingly transmitted between humans by $A e$. aegypti as a domestic/peri-domestic disease [11]. Generally, more than $90 \%$ of cases occur in sub-Saharan Africa [134], where an estimated 51,000 to 380,000 severe cases of yellow fever occur each year with 19,000 to 180,000 deaths $[67,135]$. Given the widespread distribution and abundance of Ae. aegypti in Southeast Asia, with high human population densities ideal for disease spread, it remains a perplexing anomaly why yellow fever has not made the jump to that region [136-138]. China has an increasingly strong expatriate community in Africa, including Angola from where a number of returning workers have been diagnosed with imported YFV in various parts of China, but thus far have not resulted in establishment of local infectious foci and local transmission [138].

\section{Zika virus (ZIKV)}

Zika virus was first described from a sentinel rhesus monkey placed in the Zika Forest in Uganda in 1947, and from Aedes africanus mosquitoes collected in the same forest in 1948 [139]. Subsequent serological and other studies showed ZIKV to be widespread across the eastern and western parts of Africa, with a relatively low seroprevalence of $0.5 \%$ in French Equatorial Africa in 1954 but a much higher prevalence of $38 \%$ in a $1971-$ 1975 survey in Nigeria [140]. Other studies indicate that ZIKV has been circulating widely over Africa for decades, with exposure to the virus in at least 25 countries across the continent [141]. Until recently southern Africa south of the Zambezi River was considered to be free of Zika [142, 143]. However, an overlooked publication in Portuguese [30] reported on serosurveys showing that 10 of 249 (4\%) persons sampled at 22 localities along the length of Mozambique tested positive for Zika neutralizing antibodies [29]. Genetic investigations revealed a distinct strain of ZIKV which has been circulating across much of Asia since at least 1951, including India (1952), Thailand (1954), the Phillippines (1953) and Indonesia (1951); it is suspected that this lineage of ZIKV was probably already present in Asia during World War 2 but misdiagnosed as the far more common dengue, there being extensive cross-reactivity between Zika antibodies and dengue virus [21, 23]. ZIKV remained endemic in Africa and Asia for decades, until the Asian ZIKV lineage caused an epidemic on Yap Island (Federated States of Micronesia) in 2007 [21], and from there jumped to French Polynesia in late 2013 [22], spreading to a series of Pacific Islands between 2014 to 2016 [1] and to Brazil in early 2015 [3, 23], now advancing across South America and into Central America [1]. The average rate of spread of Zika within Brazil after initial introduction has been calculated as approximating $42.1 \mathrm{~km} /$ day [3]. Three distinct genotypes of ZIKV are recognized: West African (Nigerian cluster), East African (MR766 prototype cluster) and Asian. It has been postulated that ZIKV originated in East Africa from where it spread to West Africa and Asia [144]. The majority of ZIKV infections are asymptomatic [87]. Clinical symptoms of ZIKV illness are typical of many other arboviral infections such as chikungunya and dengue, and include fever (usually mild), rash, arthralgia, arthritis, myalgia, headache, conjunctivitis, and edema; severe cases requiring hospitalization are uncommon and fatalities rare $[87$, 140]. However, it is the consequences of infection in pregnant women many of whom give birth to babies with a range of eye, cardiac and neurological anomalies such as microcephaly that is the major concern [1]. ZIKV infections have also been linked to Guillain-Barré syndrome in at least seven South American countries $[145,146]$. Historically ZIKV was likely to have been maintained in Africa as a sylvatic cycle involving nonhuman primates and Aedes mosquitoes, with humans as incidental hosts. Elsewhere however, sylvatic cycles appear not to exist but transmission flourishes as a human-mosquito-human cycle in impoverished urban settings, involving Ae. aegypti and to a lesser extent also Ae. albopictus as primary vectors [1]. ZIKV has been isolated from a wide range of mosquitoes, including at least 17 species of Aedes, the malaria vector Anopheles gambiae, two species of Eretmapodites, and Mansonia uniformis [21]. Despite some earlier conflicting reports, it has nevertheless been shown that Culex quinquefasciatus, and possibly other Culex species, are not effective vectors [147-149] and also An. gambiae and Anopheles stephensi [147].

Additional flaviviruses for which some mosquito host data could be found are listed and basic data provided in 
Table 1, but not outlined here as very little is known about them; these include Bagaza, Bouboui, Kedougou and Yaounde viruses.

\section{Togaviridae}

The genus Alphavirus of the Togaviridae comprises a large group of medically-important mosquito-borne viruses somewhat complex in the origin, dispersal and ecology of member species. Current phylogenetic tree analyses and supporting indicators suggest that alphaviruses may have arisen from an ancestral aquatic habitat, as reflected in the Southern elephant seal virus SESV and various fish viruses, a poorly studied field. Spread then expanded from southern oceans to both the New World and Old World, invading terrestrial hosts, with historical repeated re-introductions across the globe predating significant-scale human shipping and other transport likelihood. Zoonotic hosts are likely to have assisted this spread, in particular birds, but the picture and its underlying evidence requires further study [150]. Unlike flaviviruses which have clear evolutionary and ecological relationships with specific vector groups, the alphaviruses are less clustered. Aedes and Culex mosquitoes are important vectors, but with other genera such as Anopheles also involved. Alphaviruses have subgenomic promoters and dual polyproteins that facilitate more frequent changes in host range and vector range, plus a capacity for more mutations to be incorporated [150]. This has epidemiological consequences that make for more rapid spread of alphaviruses and also genetic recombination.

\section{Chikungunya virus (CHIKV)}

The first accurately diagnosed outbreak of Chikungunya (CHIKV) was described from an epidemic in Tanzania in 1952 [17]. Multiple subsequent outbreaks occurred in Africa and SE Asia in the period after 1953 [14, 151]. However, a surge of spread and large outbreaks from the mid-2000s initiated concern, associated with a mutation within CHIKV, enabling it to more easily multiply within the midgut of vector mosquitoes and leading to a 100fold increase in viraemia within the salivary glands [14, 152, 153]. Three genotypes are recognized: East/Central/ South African, West African, and Asian [15]. Commencing in 2004, near global explosive epidemics occurred originating from the East/Central/South African lineage, spreading to Indian Ocean islands, India, Asia, and also Europe and the Americas, where it affected millions of people. An outbreak in the Indian Ocean island of La Reunion in 2005-2006 infected 266,000 people, approximately one-third of the human population. In India in 2006-2007 an epidemic of CHIKV resulted in 1.42 million reported cases [16]. Thailand reported in excess of 49,000 cases for 2008-2009 [154]. CHIKV had not been known from the Americas prior to 2013, but the presence and autochthonous transmission of the virus was reported from the Caribbean island of St Martin in December 2013, and then very rapidly spread within the next year to be reported from 43 countries or territories in the Americas with more than 1.1 million suspected cases. During the period January 2015 to November 2016 an adiitional 1.2 million cases were reported from the region [154]. CHIKV is now widespread across the globe, giving rise to increasing concern as a public health threat. Phylogenetic studies indicate that the eastern half of Africa is the historic origin of CHIKV from where it subsequently spread; CHIKV is closely related to two other arboviruses of African origin, o'nyongnyong and Semliki Forest viruses [17, 18]. In Africa, local transmission of CHIKV has been reported from most sub-Saharan countries [155], with a full list of affected countries listed in Table 1. Symptoms of CHIKV include fever, rash, arthralgia, myalgia and headache, and may in rare instances lead to severe manifestations of neurological disease, myocarditis, and multi-organ failure, which may be fatal [156]. Infection is usually not life-threatening, but can persist for years associated with pain and swelling mostly in the wrists, hands, ankles and feet [157]. Important sylvatic vectors in Africa are Aedes africanus, Ae. furcifer, Ae. cordellieri [62, 158], also Ae. taylori, Ae. neoafricanus and Ae. luteocephalus [151], but under urban conditions Ae. aegypti and Ae. albopictus are the main vectors [156]. Aedes albopictus is acknowledged as the most important global vector of CHIKV [159], in large part due to a genetic mutation within the virus which enabled it to increase transmissibility to Ae. albopictus but with little impact on infectivity to Ae. aegypti [17]. Historically, CHIKV was maintained in an enzootic sylvatic cycle in Africa involving wild primates and forest-dwelling Aedes mosquitoes, with an abundance of serological presence in wild primates and humans throughout the moist forests and semi-arid savannas of Africa [18, 151]. Since the spread of CHIKV from Africa to other geographical regions, endemic/epidemic transmission cycles have been established with Ae. aegypti and Ae. albopictus mosquitoes transmitting the virus to humans in a mainly urban human-mosquito-human cycle [14].

\section{Middelburg virus (MIDV)}

Middelburg virus was isolated in 1957 from pools of $\mathrm{Ae}$ des mosquitoes during an outbreak of disease among sheep in the Middelburg area of the Cape Province in South Africa [160]. Subsequent antibody surveys in what is now the KwaZulu-Natal Province of South Africa showed positive reactions for MIDV in humans, cattle, sheep and goats $[35,101]$. Tissue samples from 623 horses with unexplained febrile and acute neurologic 
infections sent in by veterinarians across South Africa for diagnostic assays between 2008 and 2013 indicated 44 (7.1\%) positive for MIDV, several co-infected with other viruses such as SHUV and WNV [161]. In horses, symptoms of infection can be severe and resemble that of African Horse Sickness [162], including fever, stiffness, swollen limbs, hyperreactiveness, and depression, frequently associated with neurological manifestations such as paralysis, recumbency and seizures, occasionally ending in death [161, 163]. Specific mosquito species that have been found to host the virus include Aedes caballus and Mansonia africana [164]. Aside from South Africa, MIDV has also been recorded from Zimbabwe, Cameroon, Kenya, Senegal and the Central African Republic [164, 165].

\section{Ndumu virus (NDUV)}

Ndumu virus was first described in 1961 from pools of mosquitoes captured in the northern KwaZulu-Natal area of the eastern seaboard of South Africa [40]. Intracerebral and intraperitoneal injection into new-born and adult mice was fatal with lesions typical of viral encephalitis. A non-immune vervet monkey Cercopithecus aethiops pygerythrus inoculated intracerebrally developed viraemia but no signs of illness. Serological tests on rural people in eight widely scattered locations suggest that NDUV is endemic over a large area of southern Africa but no known associated morbidity [39, 40]. The mosquitoes from which virus was obtained in South Africa were Mansonia uniformis and Aedes circumluteolus [40]. In Kenya, a survey at three different habitat locations during which a total of 450,680 mosquitoes were captured, revealed that most mosquitoes and most virus was present at a floodwater location and especially from the floodwater-breeding Aedes mcintoshi, Aedes ochraceus and Aedes tricholabis, which yielded high levels of NDUV but also other viruses such as Sindbis, Babanki, Usutu, Bunyamwera, Pongola and Ngari; lakes and other large bodies of water were dominated by other genera of mosquitoes and some NDUV isolates were obtained from Culex rubinotus and Mansonia species $[93,166]$.

\section{O'nyong-nyong virus (ONNV)}

O'nyong-nyong virus was isolated as the cause of a major epidemic of dengue-like illness in 1959-1962 involving approximately 2 million people, commencing in north-west Uganda and spreading to adjoining Congo, Sudan, Kenya and Tanzania, ultimately reaching Mozambique to the south and Senegal to the north-west [45, 167]. During 1996-1997 a second epidemic of ONNF occurred, restricted to south-central Uganda but with high infection rates of between 45 and $68 \%$ of people in affected regions; symptoms of the disease included acute fever with associated polyarthralgia but no known fatalities [45]. Initially suspected of being a new and separate virus, the closely-related Igbo-Ora virus which occurs in west-central Africa manifests with very similar symptoms; genetic analyses suggest it is a strain of ONNV [168]. ONNV has been repeatedly isolated from Anopheles funestus and Anopheles gambiae in different areas, and the fact that ONNV is absent from one particular area in Uganda from which the two mosquito species are also absent but both occur in neighbouring regions provides strong evidence that the main vectors are indeed these two anthropophilic mosquito species [167]. ONNV is unique among the mosquitoborne viruses in that it is the only known virus with Anopheline mosquitoes as primary vectors, unlike other viruses that have primarily Culicine vectors [151]. However, ONNV has also been found in one pool of Mansonia uniformis, a common and widespread mosquito in Africa which also readily feeds on humans, thus demonstrating the potential for this species to play a role in ONNV epidemiology [169]. A vertebrate reservoir host for ONNV is not known [151].

\section{Semliki Forest virus (SFV)}

Semliki Forest virus was first isolated from Aedes abnormalis-group mosquitoes captured in 1942 in Uganda [170]. SFV was also isolated from Aedes argenteopunctatus mosquitoes collected in central Mozambique in 1959 [171]. Mice injected with SFV invariably developed hind-leg paralysis and convulsions followed by death $[170,171]$, while rabbits showed fever and paralysis [170]. Rhesus monkeys injected with SFV did not show any subsequent symptoms [170] but infected vervet monkeys showed fever with no other symptoms [171]. Little appears to be known regarding clinical symptoms in humans, although serosurveys from rural inhabitants in the coastal lowlands of northern South Africa and in central Mozambique revealed SFV positivity rates of $6 \%$ and 5\%, respectively [171]. Apart from South Africa and Mozambique already mentioned, SFV is also known from Cameroon, Central African Republic, DR Congo, Nigeria, Senegal and Uganda [164].

\section{Sindbis virus (SINV)}

Sindbis virus was first isolated in 1952 from a sample of $C x$. pipiens and $C x$. univittatus mosquitoes captured in the Sindbis Health District north of Cairo [172]. SINV has since been found to occur widespread within a geographical block running from South Africa up through Africa with known isolations from Uganda, Kenya, Cameroon and Egypt, then through Israel and fanning out deeply into Europe, reflecting migratory bird pathways $[115,173,174]$. There is another north-south block of SINV presence between China and the 
Philippines down to Australia [173, 174]. In Finland SINV is also known as Pogosta disease and causes regular epidemics involving hundreds or even thousands of human cases, usually in late summer, and similar disease occurs in Sweden (where it is known as Ockelbo disease) and Russia (Karelian fever). SINV was not detected in Finland during seroprevalence surveys for mosquitoborne viruses in humans prior to 1965 [175], then became prevalent and rose considerably between 1981 and 1985 , with $0.6 \%$ seroprevalence in pregnant women in 1992 [176], rising to $5.2 \%$ in a sample of 2529 people tested between 1999 and 2003 in Finland, suggesting that SINV may have been newly introduced into northern Europe sometime during the 1960s to 1970s [177]. In South Africa, during the same outbreak of West Nile virus in 1974 as discussed under WNV above, 16\% of the affected human population showed antibodies to SINV [49]. Another dual outbreak of West Nile virus and SINV in 1983 and 1984 in the Witwatersrand Pretoria area of South Africa resulted in hundreds of Sindbis human cases, but no fatalities. Also in South Africa, tissue samples from 623 horses with unexplained febrile and acute neurologic infections across the country during 2008-2013 showed 1.3\% PCR-positive for SINV, 3 of 8 infected horses dying from neurologic sequelea [161]. The disease typically is associated with arthralgia, rash and malaise in humans $[106,110]$. In southern Africa SINV cycles within a range of species of wild birds with $C x$. univittatus mosquitoes as the main vectors in the temperate inland plateau regions, while another bird-feeding species Culex neavei is the primary vector in the coastal lowlands of north-eastern South Africa. Both species of mosquitoes are capable of transmitting SINV to humans, although Cx. univittatus is a more efficient vector and accounts for the higher prevalence of human cases in the higher-lying inland areas of southern Africa [62]. In Kenya SINV has also been isolated from a range of Culex species [93]. There is evidence from genetic studies that migratory birds play a major role in the transcontinental movement of SINV, infecting mainly $C x$. pipiens, $C x$. torrentium and Culiseta morsitans mosquitoes upon arrival in northern Europe [177]. In Sweden a sero-survey in birds specifically for SINV showed antibody prevalence of $2 \%$ in $2002,8 \%$ in $2003,14 \%$ in 2004, and $37 \%$ in 2009; highest prevalence was within birds of the family Turdidae [178].

Babanki virus is listed under Togaviridae in Table 1 as some basic data are available, but insufficient for discussion in this section.

\section{Bunyaviridae}

The Bunyaviridae is a large family with medicallyimportant arboviruses clustered into the genera Orthobunyavirus (mainly mosquito-borne), Phlebovirus (mostly sand fly-borne but some mosquito-borne) and Nairovirus (mainly tick-borne). Phylogenetic reconstruction suggests ancestral associations with arthropods at deep nodes indicative of an arthropod origin for all bunyaviruses [179]. Extensive and rapid genetic reassortment within these 3-segmented viruses has resulted in evolutionary proliferation and diversification of virus species, also affecting pathogenicity, host range and vector range [180, 181]. This apparent ease and frequency of genetic reassortment has given rise to occasional uncertainty about assigning some genetically-overlapping viral isolates and could give rise to misunderstandings about disease outbreak descriptions; examples include Batai virus (BATV) and Ngari virus (NRIV) which are almost indistinguishable [41]. The majority of medicallyimportant mosquito-borne viruses in this family occur within the genus Orthobunyavirus, most transmitted by Culex mosquitoes. Aedes also form an important group of vectors and Anopheles to a lesser extent. Rift Valley fever with an exceptionally wide range of non-specific mosquito vectors is somewhat of an anomaly among the primarily sandfly-transmitted viruses in the genus Phlebovirus [181].

\section{Viruses in the genus Orthobunyavirus (Bunyaviridae)}

Bunyamwera virus (BUNV). Bunyamwera virus was first isolated in 1943 from Aedes mosquitoes in the Semliki Forest of Uganda [182] and in 1955 a different strain from Aedes circumluteolus mosquitoes in the northern coastal area of KwaZulu-Natal Province in South Africa [183]. Virus was subsequently obtained from the same KwaZulu-Natal Province area from an adult male mosquito catcher presenting with severe headache, neck stiffness and fever [33], while another study in the same area in the 1950s showed 54\% seropositivity in adult humans [35]. Serology also indicated BUNV to be common in the Okavango Basin of Botswana and Caprivi Region of Namibia [34]. Ae circumluteolus was commonly found to be infected with the virus and is likely to be important in human-human transmission, even though it is only poorly attracted to people. Neutralizing antibodies were found in a range of water birds in KwaZulu-Natal Province of South Africa [183].

Bwamba virus (BWAV). Bwamba virus was first recovered from febrile road construction workers in the Bwamba Forest (Bundibugyo) region of Uganda in the late 1930s; affected persons typically manifested rapid onset of illness with moderately severe symptoms of fever, headache and backache [31, 32]. Human fatalities have been recorded [28]. BWAV has also been isolated from human patients in multiple other countries in Africa, including Nigeria, Cameroon, Central African Republic, Kenya, Tanzania, Mozambique and South 
Africa [27]. Despite very low rates of diagnosis and reporting, it is said to be among the most common arthropod-borne diseases in Africa [27], with seropositivity in excess of $90 \%$ in some populations [28]. Virus has been isolated from a range of mosquitoes, primarily the anthropophilic Anopheles funestus and An. gambiae but also Aedes furcifer and other Aedes species, as well as Anopheles coustani and Mansonia uniformis [31].

Germiston virus (GERV). Germiston virus was first isolated in 1958 from mosquitoes collected at a reedfringed lake in the town of Germiston close to Johannesburg, South Africa. Virus was obtained from a mixed pool of Culex theileri/Culex rubinotus and another pool of pure $C x$. rubinotus. Two laboratory workers became infected while conducting serological studies, one experiencing fever, severe headache and lower back pain, the other with less severe symptoms. Laboratory tests excluded possibility of infection with the closely related Bunyamwera or other viruses [36]. Antibody surveys indicated GERV to be common among residents in the Okavango Basin of Botswana and Caprivi Region of Namibia [34].

Ilesha virus (ILESV). Ilesha virus was recorded for the first time in 1957 from a hospitalized young girl in western Nigeria [37]. The virus has subsequently been isolated from patients in Cameroon, CAR, Nigeria, Senegal, Uganda as well as Madagascar, and antibodies found in persons from Ghana and Niger [184]. Infection with ILESV is accompanied by fever, headache, myalgia of roughly 1 week duration, and in at least two of the very few cases on record led to fatal meningo-encephalitis or fatal haemorrhagic fever [37]. The virus has also been isolated from Anopheles gambiae mosquitoes in Central African Republic [185].

Lumbo virus (LUMV). Lumbo virus was isolated from coastal salt-water breeding Aedes pembaensis in northeastern Mozambique in 1959 and 1960, with 100\% mortality when inoculated into mice, but primate vervet monkeys, yellow baboon and bush babies developed antibodies without evident illness; $12.5 \%$ of a sample of 128 human sera collected in northeastern Mozambique and northern Kwazulu Natal, South Africa, contained neutralizing antibodies [38].

Ngari virus (NRIV). Ngari virus was first isolated from Aedes simpsoni mosquitoes in 1979 and from humans in 1993, both in Senegal [186]. The virus was associated with a large-scale outbreak of febrile disease in Sudan in 1988 (in some publications incorrectly ascribed to the closely-related BATV) and in Kenya, Tanzania and Somalia in 1997-1998 [41]; in both sets of outbreaks the events were preceded by unusually heavy rain and floodpromoted mosquito breeding. In the Sudan outbreak at least $18 \%$ of the 77,500 febrile cases were clinically diagnosed as malaria, but virus isolates and immunoglobulin from a sample of 195 sera suggest at least $7 \%$ were due to NRIV. The large outbreak in Kenya and Somalia involving around 89,000 human infections with 250 deaths was ascribed to Rift Valley fever, but $27 \%$ of a sample of approximately 115 acute haemorrhagic cases was due to NRIV based on PCR and/or IgM antibody, while RVF could only be confirmed in $23 \%$ of such haemorrhagic cases $[41,43]$. NRIV is stated to be more virulent than BUNV and BATV and is associated with hemorrhagic fever [42]. The virus has also been found in sheep and goats in Mauritania [42].

Shuni virus (SHUV). Shuni virus was first isolated in 1966 in Nigeria as part of surveys covering livestock, mosquitoes and Culicoides biting midges [48, 164]. It is a cause of neurological disease and associated mortality in domestic and wild animals. Symptoms in horses include depression, anorexia, ataxia, tremors, convulsion, and recumbency with paddling of legs. RT-PCR assays on tissue samples submitted by veterinarians in South Africa indicated 8\% SHUV positivity in a sample of 26 horses with fever and $6 \%$ of 86 horses with nervous disease [187]. In 2014 two herds of sheep in Israel were noted to show arthrogryposis-hydranencephaly syndrome; 27 tissue samples from these sheep (15 individuals) as well as cattle and goats showed $85 \%$ positive for Shuni virus by PCR [188]. SHUV sero-prevalence of $3.9 \%$ was found in a sample of 123 South African veterinarians working with horses and wildlife [48]. Shuni virus has been isolated from pools of Culex theileri mosquitoes collected near Johannesburg in South Africa [26].

Witwatersrand virus (WITV). Witwatersrand virus was isolated from a pool of 20 Culex rubinotus mosquitoes collected at the same lake as Germiston virus was discovered, also in 1958, near the city of Johannesburg, South Africa [53]. WITV was subsequently found to be present fairly regularly in pools of $C$. rubinotus collected in South Africa and Zimbabwe, suggesting that this mosquito is a maintenance vector for WITV and also several other viruses such as Banzi (Flavivirus) and Germiston (Orthobunyavirus) viruses [61]. Nothing is known regarding the significance of WITV for human health, although a serological survey in the north-eastern coastal area of South Africa and in Mozambique suggested the virus to be present in humans in those areas; no antibodies were detected from humans in the Johannesburg Witwatersrand area in which the virus was first 
discovered. Injection of WITV into infant and adult mice proved lethal [53].

Additional viruses with little published data are listed in Table 1, including Batai, Nyando and Pongola.

\section{Viruses in the genus Phlebovirus (Bunyaviridae)}

Rift Valley fever (RVFV). First described from Kenya in 1931 [189], Rift Valley fever virus (RVFV) has been diagnosed widely across Africa (see Table 1), Madagascar and the Arabian Peninsula [190, 191]. It gives rise to periodic outbreaks sometimes with dramatic impact, such as an outbreak in South Africa in 1950-1951 causing the death of more than 100,000 sheep and 500,000 abortions. Outbreaks also occur amongst other domestic animals such as goats and cattle, major events having occurred in Mozambique, Namibia, Zambia, Zimbabwe and several other southern and eastern African countries $[46,47]$. Human infections are regularly associated with such epizootics, including an unprecedented outbreak of up to 200,000 cases and 598 fatalities amongst people in the Nile valley and delta in Egypt in 1977-1978. RVF is mostly recognized from high rates of abortion and high mortality in new-born offspring in domestic ruminants such as sheep, but with associated low numbers of infections and deaths in humans [46, 47]. The disease usually presents itself in humans as mild febrile illness typically with malaise, headache, myalgia, nausea, but can lead to serious complications and death. In a major study to determine vectors of RVFV in Kenya, some 164,626 identified mosquitoes (of 297,000 collected) were sorted in pools of which the following species tested positive, in descending order of frequency: Aedes mcintoshi/circumluteolus (26 pools), Aedes ochraceus (23 pools), Mansonia uniformis (15 pools); Culex poicilipes, Culex bitaeniorhynchus (3 pools each); Anopheles squamosus, Mansonia africana (2 pools each); Culex quinquefasciatus, Culex univittatus, Aedes pembaensis (1 pool each) [192]. Various species of Aedes, Culex and also Eretmapodites have also been found positive for RVFV in other studies [26] and also Mansonia africana [191]. In southern Africa RVF virus has been isolated from a number of Aedes species either from the field or under experimental conditions, the key species most likely to have important roles in virus transmission being Ae. caballus, Ae. juppi, Ae. mcintoshi and Ae. circumluteolus. These Aedes species probably serve to initiate early-season infection in ruminant hosts which is then expanded into epizootic proportions by more prolific Culex species breeding in large bodies of water, such as Culex theileri, $C x$. zombaensis and Cx. quinquefasciatus [62, 193]. There is some evidence that RVF virus is carried transovarially to subsequent generations of Aedes mosquitoes via eggs that can withstand extended periods of drought [194]. These so-called floodwater breeding Aedes species lay their eggs in seasonal pans that dry up during the dry season and the eggs hatch once rain returns the next season or even in subsequent years. Significant effort has been devoted towards developing mathematical and climate models to predict RVF outbreaks [195, 196].

The preceding outline of viruses isolated from Africa, known to infect humans and vectored by mosquitoes, demonstrates not only that several of these viruses have made intercontinental jumps to become major public health challenges, but also that a good number remain in quiescent mainly sylvatic situations with unpredictable potential for future impact, maintaining an "underthe-radar" presence but known to be infective to humans. Table 1 summarizes the discussion above. Below is an outline of the ecological context and other factors that play a role in the potential future spread of one or more of these viruses.

\section{Predisposing factors favouring the survival, spread and incidence of mosquito-borne arboviruses}

Three things are usually necessary for transmission, maintenance and spread of arboviral diseases: the pathogen (virus), the vector (mosquito or tick etc.), and an appropriate virus-replicating host (bird, primate etc.). All three elements must have contact with each other sufficiently often for the virus to make its way along the next link in the cycle to ensure perpetuation of the virus, otherwise local infection and ultimately the species of virus will die out. Sometimes the virus finds alternative pathways for more direct transmission, such as directly between humans through sperm or blood transfusion as with Zika, but these are the exception. Sometimes mosquitoes transmit the virus to a dead-end host, as is the case with many of the arboviruses listed in this paper, where humans are accidental infections that play no essential part in the natural cycling and maintenance of the virus, but it has major consequence because it causes disease or death in humans. The infected humans do not build a sufficiently high viraemia to re-infect other mosquitoes which would enable environmental increase in the virus and therefore increase transmission opportunity and survival chances of the virus; instead the virus is "wasted" in infecting a human which does not lead to onward passage.

However, sometimes an event or situation arises that brings about a quantum jump in the ability of the virus to increase its spread, break out of the historic limiting conditions that restricted its localized distribution and smouldering low-impact presence. These events lead to epidemics and pandemics and major shifts in geographical, economic and health impact. Such break-outs from historic constraints may be temporary or permanent. They include events such as adaptive shifts that enable 
mosquito populations to depart from a previous sylvatic existence to a strongly human-adapted co-existence, genetic mutations that enable a new strain of virus to more effectively infect and be transmitted by a particular mosquito, mutations that result in entirely new species of viruses that have set up new diseases, and new modes of international transport being provided to mosquitoes pre-adapted to take advantage of such transport. A range of these predisposing factors favouring increase and spread of arboviruses is discussed below.

\section{Human population growth and its ramifications}

The more people there are and the more densely they are spaced, the more hosts and easier accessibility there is for blood-feeding anthropohilic mosquitoes especially in urban environments. Higher human population numbers also mean more waste which creates habitat for container breeders such as Aedes, or polluted pools and streams for Culex, usually in the extensive poorer and less sanitary city areas with household incomes not allowing adequate personal protection from mosquitoes. It took hundreds of thousands of years for the human population to reach a total of 1 billion people, which it did in the year 1800; it then took 150 years to grow to 2.5 billion people in 1950 [197]. Just short of 70 years later, the global population now stands at over 7 billion people and is projected to reach 8.1 billion by 2025 and 9.6 billion by 2050 [24]. This rapid and massive population growth is associated with increasing urbanization and international migration [197]. In 2014, close on 54\% of people lived in urban areas, and projections are that by 2050 about $66 \%$ of the global population will reside in cities [198]. Most populations in sub-Saharan Africa are anticipated to double in size [24], translating into increased human movement into historic forested areas to access more land and therefore exposure to the multiple arboviruses existing in sylvatic cycles. It is self-evident that these population increases, increasing urbanization, and increased international traffic will provide very significant opportunity for an increase in spread and growth of mosquitoes and virus and associated arboviral disease.

\section{Global trade, tourism and other opportunities for geographical leaps}

Trans-national and intercontinental transfer of infected vector mosquitoes or their eggs are among the most important methods for rapid geographical leaps in distributions of arboviruses. Examples include transport of Ae. aegypti in ships centuries ago to spread yellow fever from Africa to South America, still ongoing since that time $[8,58,129,136,199,200]$, and Ae. albopictus primarily via the used-car tyre export trade [78, 201-205]. It is precisely this feature of international spread through human-facilitated means $[76,206]$ that has made dengue, chikungunya, Zika and other viruses such global public health threats and brought Ae. aegypti and Ae. albopictus such importance as probably the two most important disease transmitters on the planet. Were it not for the international spread of these two mosquitoes by human assistance the arboviruses they transmit would not have anywhere near the impact and importance they currently have, and the diseases would likely still have been confined to their original pockets of historic endemic distribution. West Nile virus too, a Culexassociated arbovirus using birds as amplifying host, made the jump to North America [173], apparently from Africa or the Middle East as suggested by genetic evidence [159] and is suspected to have happened via mosquitoes on board aircraft [173].

Aircraft passenger numbers have increased on average nearly $9 \%$ per annum in the half-century preceding the mid-2000s [207]. With well over 1 billion foreign arrivals in 2016, international tourism trends have continued to grow. The number of tourists travelling to Asia and the Pacific increased by $>8 \%$ in 2016, equalled by $>8 \%$ tourism growth into Africa [208]; these are precisely the regions with the greatest reservoirs of arboviruses in the world and projections are that the rises in tourism trends will be sustained [208].

Growth in world trade, despite being referred to as "sluggish", has shown overall rise in preceding years and is expected to increase by $3.6 \%$ in 2017 according to World Trade Organization economists [209]. Shipping traffic increased by more than $27 \%$ in the period 1993 to 2006 [207]. The middle class is growing in the emerging economies of Asia, Africa and Latin America, and as disposable income increases, so too does the demand for imported products, directly correlated with shipping [210]. Upon arrival at a new destination, some anthropogenically-relocated vectors - including Ae. aegypti - have shown strong competitive ability to displace local mosquito species, enabling them to establish a foothold and disperse [211].

With a steadily expanding human population and a larger middle class with increasing disposable income, international traffic to satisfy tourism and import demands will continue to provide opportunity for movement of vectors and virus, including from Africa where a range of viruses of as yet unknown potential for public health impact are known to occur. Such opportunity for movement of disease is not limited to trade and tourism, as there is a steadily increasing number of people visiting friends and relatives, pilgrimages, humanitarian and other volunteer work, large numbers of politically and ecomically displaced refugees, all contributing to the potential for infected persons to carry pathogens to other geographical shores and infect local vectors [212]. The 
international or regional movement of livestock, often done informally and laissez faire across national boundaries between countries, is a serious risk factor for spread of virus such as Rift Valley fever where local comptetent vectors may be present in as-yet uninfected countries [213].

\section{Vertical trans-generational transmission of virus}

Transmission of virus between mosquitoes, birds, humans and other vertebrates is known as horizontal transmission, but there is also trans-generational vertical transmission of virus within some vector species allowing passage of infective virus from adult mosquitoes to offspring [214]. The terms "transovarial transmission" and "vertical transmission" are sometimes used interchangeably by some authors, despite transovarial passage being a subset of vertical transmission. Such vertical transmission of virus from one generation of mosquitoes to the next appears uncommon among mosquito-borne alphaviruses, has intermediate occurrence in flaviviruses but high frequency among bunyaviruses [215]. Alphaviruses have been found on the egg-surfaces but the egg rarely becomes infected, apparently due to absence of virus in the ovarioles themselves but presence in the lateral and common oviducts where contamination could occur. A similar situation exists in several flaviviruses that have been studied, where eggs become infected by a poorly understood mechanism, which is also not transovarial as the follicles are not involved in infection and instead the mature egg is somehow infected during oviposition. True transovarial transmission happens among several bunyaviruses, by way of germinal tissue infection. The latter method results in very high vertical transmission rates [215].

Among flaviviruses, vertical transmission of dengue-2 virus (DENV-2) in Ae. albopictus has been demonstrated in laboratory studies in India [216]. Angel and Joshi [217] collected larvae from pots and other containers in domestic and peri-domestic areas in Jodhpur, Jaipur and Kota districts in India, reporting vertically transmitted dengue virus in up to $13.3 \%$ of Ae aegypti, 18.7\% of Ae. albopictus, and and $20 \%$ of Ae. vittatus adults reared from such collected larvae. Natural vertical transmission of dengue virus has also been demonstrated in northeastern Brazil, the authors reporting DENV-2 and DENV-3 from Ae albopictus, and DENV-2 from Ae. aegypti, these mosquitoes having been reared from larvae and pupae collected in households in Fortaleza city [218]. Experimental transovarial and vertical transmission of YFV has also been confirmed for Ae. aegypti in several studies [219-221], while natural vertical transmission of YFV by Ae. aegypti was confirmed in Senegal, Africa [222]. Such vertical transmission is not limited to

Aedes however. Experimental and natural vertical transmission of WNV has been reported for Culex tarsalis and Culex pipiens complex in California, including multiple examples of female Culex passing WNV to progeny [223]. Experimental vertical transmission of WNV was also demonstrated in Culex tritaeniorhynchus, and also in Ae. aegypti and Ae. albopictus [224]. Haemagogus equinus females were also experimentally infected in Panama with DENV-1 and this was successfully passed to egg-stage and subsequently to fourth-stage larvae [225].

Among the alphaviruses, vertical transmission of CHIKV has been confirmed in Aedes aegypti mosquitoes in northern India [226], and in Thailand it was vertically transmitted experimentally to F5 and F6 generations of Ae. aegypti and Ae. albopictus, respectively, with Ae. albopictus being more susceptible and with greater ability for vertical transmission [227].

At least one publication suggests that transgenerational vertical transmission of virus, at least in the case of dengue, is unlikely to be important in the epidemiological persistence of dengue viruses [228].

\section{Dessication-resistant eggs}

The ability to pass virus on from one mosquito generation to the next by way of infected eggs (vertical transmission) is a major adaptive advantage to increase the likelihood of virus survival in the environment, helping to reduce the chances of local extinction of the virus at a particular geographical focus. However, the combination of this trait - successful passage of viable virus from one female mosquito via the eggs and larvae to the next generation of adult females - with eggs that are also desiccation resistant adds a truly powerful dual mechanism not only for survival of virus but also geographical spread. This phenomenon of some mosquitoes being able to lay eggs that can survive variable periods of complete drying out and hatch at the next inundation by rain or floods or humans watering a garden, and even have staggered hatching events spread over multiple inundations, is probably the single most important biological trait that (in combination with strong anthropophily) has allowed such effective global spread of $A e$. aegypti and Ae. albopictus and as a consequence also their associated diseases of DENV, CHIKV, YFV and others.

The phenomenon of being able to lay drought - or desiccation-resistant eggs is best known within the Aedes subgenus Stegomyia, species of which tend to be container breeders laying eggs in small volumes of water subject to drying up, hence placing an evolutionary advantage on populations which developed the ability to survive such episodes of drying up. These species now even lay their eggs above the water-line in small pools, effectively encouraging drying out and survival until the 
next inundation or flooding event when more water is likely to be available for the full larval development period [229].

The ability to lay desiccation-resistant eggs has been proven for multiple Aedes (Stegomyia) species, including Ae. aegypti and Ae. albopictus [229-231]. Aedes aegypti eggs have been shown to survive under very different humidity regimes, with a mean dry-egg survival period of 128 days at $88 \%$ relative humidity, while Ae. albopictus generally had lower survival with mean of 78 days at $88 \%$ RH [229]. Other studies have confirmed survival of Ae. aegypti dry eggs up to or exceeding 4 months in Tanzania [232, 233] or 5 months in Queensland, Australia [234] under outdoor natural conditions; reports also exist for egg survival of Ae. albopictus exceeding 5 months [235]. It is therefore clear that both $A e$. aegypti and Ae. albopictus could easily survive extended periods of trans-oceanic transport as dry eggs in cartyres or other containers.

One of the enduring puzzles has been how RFV is maintained between epidemics which may have a decade or more separating such events; speculation has long existed that transovarially-infected or vertically transmitted eggs of Aedes that are drought-resistant and survive for many years may be responsible or contribute to such inter-epidemic survival [194, 196].

\section{Virus mutations}

Virus evolution by way of mutation, genome segment reassortment or recombination is one of the contributory factors to the occurrence of emergent and/or reemergent viral diseases [236]. High frequency reassortment can occur when mosquitoes are infected with two viruses most likely arising from interrupted feeding and moving from one host to another to complete a bloodmeal, or separate infected bloodmeals one or 2 days apart. That such reassortment does happen is well established, for example Ngari virus which is a reassortment between Bunyamwera and Batai virus [43, 236]. Reassortments of different strains of Rift Valley fever virus have also been found in East Africa [237]. The singlestranded RNA bunyaviruses are particularly prone to produce genetic variants and many of these variants have been detected from field situations [238]. Not only are reassortments able to produce new viruses with new epidemiologies, virulence and pathologies, but relatively minor mutations are also capable of dramatically affecting vector susceptibility enabling quantum improvements in transmission efficiency in previously inefficient vectors or even new vectors to transmit the virus. A case in point is the single amino acid change in the EI envelope glycoprotein of chikungunya virus. CHIKV historically had an alanine amino acid at position 226 in EI and this virus was transmitted mainly by Ae. aegypti; a single mutation resulting in a valine amino acid at position 226 greatly enhanced virus replication within - and transmission by - Ae. albopictus [153, 239, 240] and led to the widespread dispersal of CHIKV in regions of Asia where Ae. albopictus predominated [236], as well as an outbreak in northern Italy where Ae. aegypti did not occur [241]. These events all potentially contribute to the survival, spread and increased incidence of mosquito-borne arboviruses.

\section{Vector mutations and adaptations}

Not only do the viruses that cause disease mutate or show adaptive selection for optimized transmission, but so do the vectors. Aedes aegypti is one example. This historically forest-dwelling zoophilic species adaptively transformed into a highly anthropophilic urban-adapted "domesticated" form responsible for transmitting several of the most serious public health challenges on the planet. The "domestication" adaptation enabled Ae. aegypti aegypti to spread with humans to almost all tropical and sub-tropical parts of the world, where it is now a major vector for dengue, chikungunya, and yellow fever in some regions [242, 243]. Other examples also exist of adative shifts that enable vector mosquitoes to evade control attempts, resulting in dramatic resurgence in disease. Such examples are common especially in malaria control, where vector resistance to pyrethroid and other insecticides has evolved on numerous occasions in multiple countries, causing serious setbacks in disease control programmes [244-249]. Similar and escalating trends of insecticide resistance have also been recorded for non-anopheline species, such as Ae. aegypti [250-254], to some extent in Ae. albopictus [251, 254, 255] and various Culex species including $C x$. pipiens [256] and Cx. quinquefasciatus [256-258].

\section{Climate change}

Climate change embraces the suite of projected climatic parameters that are already in the process of shifting from historic norms and "natural" background longterm cycles, these changes brought about by massive anthropogenic emmissions of gases that affect meteorological processes. The expert Intergovernmental Panel on Climate Change (IPCC) produces periodic assessment reports which consistently show a steady warming of the planet that is set to continue for the remainder of this century [259]. The consequences of these "greenhouse-effect" rising temperatures will be fundamental and wide-ranging changes in average daily temperatures, precipitation, flood and drought events and various other climate-related parameters, but with a broad likelihood that these changes will in many geographical regions favour the spread of disease vectors and their abundance $[239,260]$. However, the interaction of 
various factors is complex, making predictions of likely vector increases or disease spread difficult [236, 261].

Global warming and other climate change-related factors have already resulted in predictions of further spread of Ae. albopictus in Europe by 2030 [236, 261, 262]. The spread and establishment of arboviruses such as RVFV in Europe and the USA has also been discussed in relation to climate change [239].

\section{Conclusions}

The literature reviewed in this paper shows that there is a substantial number of mosquito-borne arboviruses present in Africa, and that several of these have already in preceding centuries or decades escaped from their historic African areas of origin to become serious public health threats at global scale. Zika is currently the most recent example of this. Many of these mosquito-borne arboviruses remain quiescent but almost certainly some of them must surely have the potential to break out under "Perfect Storm" conditions to invade other geographical regions with unknown consequences. Variour factors increase this likelihood, including expanding human populations that of necessity clear forests and woodland for cropland and increased needs of sustenance, thereby placing themselves within reach of sylvatic disease cycles, plus the everincreasing international travel and ease with which infected vectors or people can carry virus to every inhabited corner of the globe. It is therefore incumbent upon nations and governments to maintain and indeed increase vigilance against the insidious infiltration of vectors and viruses. All it takes is for a few infected mosquitoes or people or animals to establish the vector or virus which slowly simmers and grows until it emerges as a full-blown outbreak and public health emergency. This is the historic pattern of most of these diseases, be it yellow fever, dengue, chikungunya, West Nile virus, Zika and several others. Africa appears to be not only the ancestral cradle of humankind, but also the spawning ground of many zoonotic diseases, especially arboviruses. It is very likely that Africa has the greatest potential for novel zoonoses and for the next export of a previously quiescent pathogen to invade elsewhere on a rapidly changing planet.

\footnotetext{
Abbreviations

Ae: Aedes; AMTV: Arumowot virus; An: Anopheles; BAGV: Bagaza virus; BANV: Banzi virus; BATV: Batai virus; BBKV: Babanki virus; BOUV: Bouboui virus; BUNV: Bunyamwera virus; BWAV: Bwambwa virus; CHIKV: Chikungunya virus; Cx: Culex; DENV1-4: Dengue virus serotypes 1 to 4; GERV: Germiston virus; ILEV: Ilesha virus; KEDV: Kedougou virus; LUMV: Lumbo virus; MIDV: Middelburg virus; MOSV: Mossuril virus; NDUV: Ndumu virus; NDV: Nyando virus; NRIV: Ngari virus; NTAV: Ntaya virus; ONNV: O'nyong-nyong virus; PGAV: Pongola virus; RVFV: Rift Valley fever virus; SFV: Semliki Forest virus; SHUV: Shuni virus; SINV: Sindbis virus; SPOV: Spondweni virus; UGSV: Uganda S virus; USUV: Usutu virus; VEE: Venezuelan equine encephalitis virus; WESV: Wesselsbron virus; WITV: Witwatersrand virus; WNV: West Nile virus; YAOV: Yaounde virus; YFV: Yellow fever virus; ZIKV: Zika virus
}

\section{Acknowledgements}

We thank the UP ISMC \& MRC Collaborating Centre for Malaria Research of the University of Pretoria for library and other institutional support during the writing of this publication.

\section{Funding}

Not applicable.

\section{Availability of data and materials}

This paper was based on a literature survey. We searched PubMed (https:// www.ncbi.nlm.nih.gov/nlmcatalog/journals), Google Scholar, Google search and websites of relevant international organization. Search terms initially were "Arbovirus AND Africa" or "Arbovirus AND vectors", as well as the names of each of the viruses discussed in this paper as well as key vector species, such as "Dengue virus" or "Aedes aegypti". Abstracts were screened for relevance and appropriate papers then read in full. These primary papers led to other references by way of publications quoted in their texts. The data supporting the conclusions of this article are included within the article.

\section{Authors' contributions}

LB conceptualized and wrote the initial draft, with subsequent additions and editorial comments by APGA, AJC, BS and CdJ. All authors read and approved the final manuscript.

\section{Ethics approval and consent to participate}

Not applicable.

\section{Consent for publication \\ Not applicable.}

\section{Competing interests}

The authors declare that they have no competing interests.

\section{Publisher's Note}

Springer Nature remains neutral with regard to jurisdictional claims in published maps and institutional affiliations.

\section{Author details}

${ }^{1}$ School of Health Systems \& Public Health, University of Pretoria, Pretoria, South Africa. ${ }^{2}$ Instituto de Higiene e Medicina Tropical, Universidade Nova de Lisboa, Lisbon, Portugal. ${ }^{3}$ Department of Medical Virology, University of Pretoria, Pretoria, South Africa. ${ }^{4}$ Department of Entomology and Nematology, Mosquito Control Research Laboratory, Kearney Agricultural Center, UC Davis, Parlier, CA, USA. ${ }^{5}$ Department of Veterinary Tropical Diseases, University of Pretoria, Pretoria, South Africa. ${ }^{6}$ Faculty of Health Sciences, University of Pretoria, Pretoria, South Africa.

Received: 5 June 2017 Accepted: 27 November 2017

Published online: 09 January 2018

\section{References}

1. Petersen LR, Jamieson DJ, Powers AM, Honein MA. Zika virus. N Engl J Med. 2016;374:1552-63

2. Vest KG. Zika virus: a basic overview of an emerging arboviral infection in the western hemisphere. Disaster Med Public Health Prep. 2016;10(5):707-12.

3. Zinszer K, Morrison K, Brownstein JS, Marinho F, Santos AF, Nsoesie EO. Reconstruction of Zika virus introduction in Brazil. Emerg Infect Dis. 2017;23(1):91-4.

4. Lucey D, Gostin LD. A yellow fever epidemic: a new global health emergency? JAMA. 2016;315(24):2661-2

5. Centers for Disease Control and Prevention. Yellow fever in Brazil. Centres for disease control and prevention; 2017. https://wwwnc.cdc.gov/travel/ notices/. Accessed Apr 2017.

6. Ortiz-Martinez Y, Patino-Barbosa AM, Rodriguez-Moralez AJ. Yellow fever in the Americas: the growing concern about new epidemics. F1000. Res. 2017:6:398.

7. WHO. Yellow Fever - Brazil. http://www.who.int/csr/don/20-march-2017yellow-fever-brazil/en/2017. Accessed Mar 2017.

8. Bryant JE, Homes EC, Barrett AD. Out of Africa: a molecular perspective on the introduction of yellow fever virus into the Americas. PLoS Pathog. 2007:3(5):3e75. 
9. Meegan JM. Yellow fever. In: Beran GW, editor. Handbook of zoonoses. 2nd ed. Section B: Viral Zoonoses. Boca Raton: CRC Press; 1994. p. 111-24.

10. Spielman A, D'Antonio M. Mosquito: a natural history of our most persistent and deadly foe. London: Faber \& Faber; 2001.

11. Gubler DJ. The changing epidemiology of yellow fever and dengue, 1900 to 2003: full circle? Comp Immunol Microbiol Infect Dis. 2004;27:319-30.

12. Gubler DJ, Zaki SR. Dengue and other viral hemorrhagic fevers. Pathol Emerg Dis. 1998;2:43-71.

13. Messina JP, Brady OJ, Scott TW, Zou C, Pigott DM, Duda KA, et al. Global spread of dengue virus types: mapping the 70 year history. Trends Microbiol. 2014:22(3):138-46.

14. Caglioti C, Lalle E, Castiletti C, Carletti F, Capobianchi MR, Bordi L. Chikungunya virus infection: an overview. New Microbiol. 2013;36:211-27.

15. Escobar LE, Qiao H, Peterson AT. Forecasting chikungunya spread in the Americas via data-driven empirical approaches. Parasit Vectors. 2016;9:112.

16. Townson H, Nathan MB. Resurgance of chikungunya. Trans R Soc Trop Med Hyg. 2008;102:308-9.

17. Weaver SC, Forrester NL. Chikungunya: evolutionary history and recent epidemic spread. Antivir Res. 2015;120:32-9.

18. Weaver SC, Lecuit M. Chikungunya virus and the global spread of a mosquito-borne disease. N Engl J Med. 2015:372:1231-9.

19. Hollidge BS, Gonzalez-Scarano F, Soldan SS. Arboviral encephalitides: transmission, emergence, and pathogenesis. J Neurolmmune Pharmacol. 2010;5:428-42.

20. Patsoula E, Vakali A, Balatsos G, Pervanidou D, Beleri S, Tegos N, et al. West Nile virus circulation in mosquitoes in Greece (2010-2013). Biomed Res Int 2016; https://doi.org/10.1155/2016/2450682.

21. Haddow AD, Schuh AJ, Yasuda CY, Kasper MR, Heang V, Huy R, et al. Genetic characterization of Zika virus strains: geographic expansion of the Asian lineage. PLoS Negl Trop Dis. 2012;6(2):e1477.

22. Jouannic J-M, Friszer S, Leparc-Goffart I, Garel C, Eyrolle-Guignot D. Zika virus infection in French Polynesia. Lancet. 2016;387:1051-2.

23. Lanciotti RS, Lambert AJ, Holodniy M, Saavedra S, Signor LCC. Phylogeny of Zika virus in western hemisphere, 2015. Emerg Infect Dis. 2016;22(5):933-5.

24. United Nations. World population prospects: the 2012 revision. New York: United Nations Department of Economic \& Social Affairs, Population Division; 2013. p. xxi + 94.

25. Smithburn KC, Paterson HE, Heymann CS, Winter PAD. An agent related to Uganda S virus from man and mosquitoes in South Africa. S Afr Med J. 1959b;33(46):959-62

26. McIntosh B. The epidemiology of arthropod-borne viruses in southern Africa. Unpublished DSc dissertation. Pretoria, South Africa: University of Pretoria; 1980

27. Bres P. Recent data from serological surveys on the prevalence of arbovirus infections in Africa, with special reference to yellow fever. Bull World Health Organ. 1970;43:223-67.

28. Groseth A, Mampilli V, Weisend C, Dahlstrom E, Porcella SF, Russell BJ, et al. Molecular characterization of human pathogenic bunyaviruses of the Nyando and Bwamba/Pongola virus groups leads to the genetic identification of Mojuí dos Campos and Kaeng Khoi virus. PLoS Negl Trop Dis. 2014;8(9):e3147.

29. Gudo ES, Falk Kl, Ali S, Muianga AF, Monteiro V, Cliff J. A historic report of Zika in Mozambique: implications for assessing current risk. PLoS Negl Trop Dis. 2016b;10(12):e0005052

30. Kokernot RH, Smithburn KC, Gandara AF, Mclntosh BM, Heymann CS. Neutralization tests with sera from individuals residing in Mozambique against specific viruses isolated in Africa, transmitted by arthropods. An Inst Med Trop (Lisb). 1960;17:201-30.

31. Lutwama JJ, Rwaguma EB, Nawanga PL, Mukuye A. Isolations of Bwamba virus from south central Uganda and northeastern Tanzania. Afr Health Sci. 2002;2(1):24-8

32. Smithburn KC, Mahaffy AF, Paul JH. Bwamba fever and its causative virus. Am J Trop Med Hyg. 1941;s-1-21(1):75-90.

33. Kokernot RH, Smithburn KC, De Meillon B, Paterson HE. Isolation of Bunyamwera virus from a naturally-infected human being and further isolations from Aedes (Banksinella) circumluteolus Theo. Am J Trop Med Hyg. 1958;7:579-84.

34. Kokernot RH, Szlamp EL, Levitt J, Mclntosh BM. Survey for antibodies against arthropod-borne viruses in the sera of indigenous residents of the Caprivi strip and Bechuanaland protectorate. Trans R Soc Trop Med Hyg. 1965;59(5):553-62.
35. Smithburn KC, Kokernot RH, Heymann CS, Weinbren MP, Zentkowsky D. Neutralizing antibodies for certain viruses in the sera of human beings residing in northern Natal. S Afr Med J. 1959a;33:555-61.

36. Kokernot RH, Smithburn KC, Paterson HE, Mclntosh BM. Isolation of Germiston virus, hitherto unknown agent, from culicine mosquitoes, and a report of infection in two laboratory workers. Am J Trop Med Hyg. 1960b;9:62-9.

37. Morvan JM, Digoutte JP, Marsan P, Roux JF. llesha virus: a new aetiological agent of haemorrhagic fever in Madagascar. Trans R Soc Trop Med Hyg. 1994;88(2):205.

38. Kokernot RH, McIntosh BM, Worth CB, De Morais T, Weinbren MP. Isolation of viruses from mosquitoes collected at Lumbo, Mozambique, I. Lumbo virus, a new virus isolated from Aedes (Skusea) pembaensis Theobald. Am J Trop Med Hyg. 1962b;11:678-82.

39. Karabatsos N. International catalogue of arboviruses: including certain other viruses of vertebrates. 3rd ed. Centers for Disease Control and Prevention. 1985; weblink: https://wwwn.cdc.gov/arbocat//

40. Kokernot RH, McIntosh BM, Worth CB. Ndumu virus, a hitherto unknown agent, isolated from culicine mosquitoes collected in northern Natal, union of South Africa. Am J Trop Med Hyg. 1961a;10(3):383-6.

41. Briese T, Bird B, Kapoor V, Nichol ST, Lipkin WI. Batai and Ngari viruses: M segment reassortment and association with severe febrile disease outbreaks in East Africa. J Virol. 2006;80(11):5627-30.

42. Eiden M, Vina-Rodriguez A, El Mamy BO, Isselmou K, Ziegler U, Höper D, et al. Ngari virus in goats during Rift Valley fever outbreak, Mauritania, 2010. Emerg Infect Dis. 2014;20(12):2174-6.

43. Gerrard SR, Li L, Barrett AD, Nichol ST. Ngari virus is a Bunyamwera virus reassortant that can be associated with large outbreaks of hemorrhagic fever in Africa. J Virol. 2004;78(16):8922-6.

44. Woodruff AW, Bowen ETW, Platt GS. Viral infections in travellers from tropical Africa. Br Med J. 1978;1:956-8.

45. Sanders EJ, Rwaguma EB, Kawamata J, Kiwanuka N, Lutwama JL, Ssengooba FP, et al. O'nyong-nyong fever in south-central Uganda, 1996-1997: description of the epidemic and results of a household-based seroprevalence survey. J Infect Dis. 1999;180:1436-43.

46. Swanepoel R. Rift Valley fever. In: Palmer SR, Lord S, DIH S, editors. Chapter 38: Zoonoses. Oxford: Oxford Medical Publications, Oxford University Press; 1998. p. 459-68.

47. Swanepoel R, Coetzer JAW. Rift Valley fever. In: Coetzer JAW, Thompson GR, Tustin RC, editors. Infectious diseases of livestock with special reference to southern Africa. 2nd ed. Cape Town, South Africa: Oxford University Press; 2004

48. van Eeden C, Swanepoel R, Venter M. Antibodies against West Nile and Shuni viruses in veterinarians South Africa. Emerg Infect Dis. 2014;20(8):1409-11.

49. McIntosh BM, Jupp PG, Dos Santos I, Meenehan GM. Epidemics of West Nile and sindbis viruses in South Africa with Culex (Culex) univittatus Theobald as vector. S Afr J Sci. 1976b;72(10):295-300.

50. McIntosh BM, Kokernot RH, Peterson HE, De Meillon B. Isolation of Spondweni virus from four species of culicine mosquitoes and a report of two laboratory infections with the virus. SAMJ. 1961a;35(31):647-50.

51. Wolfe MS, Calisher CH, McGuire K. Spondweni virus infection in a foreign resident of upper Volta. Lancet. 1982;2(8311):1306-8.

52. Dick GWA, Haddow AJ. Uganda S virus: a hitherto unrecorded virus isolated from mosquitoes in Uganda. (1). Isolation and pathogenicity. Trans R Soc Trop Med Hyg. 1952;46(6):600-18.

53. McIntosh BM, Kokernot EH, Paterson HE. Witwatersrand virus: an apparently new virus isolated from culicine mosquitoes. S Afr J Med Sci. 1960;23(1):33-7.

54. Gould EA, de Lamballerie X, Zanotto PM, Holmes EC. Evolution, epidemiology, and dispersal of flaviviruses revealed by molecular phylogenies. Adv Virus Res. 2001;57:71-103.

55. Gould EA, de Lamballerie X, de A Zanotto PM, Holmes EC. Origins, evolution, and vector/host coadaptations within the genus Flavivirus. Adv Virus Res 2003;59:277-314.

56. Moureau G, Cook S, Lemey P, Nougairede A, Forrester NL, Khasnatinov M, et al. New insights into Flavivirus evolution, taxonomy and biogeographic history. Extended by analysis of canonical and alternative coding sequences. PLoS One. 2015;10(2):e0117849.

57. Holmes EC, Twiddy SS. The origin, emergence and evolutionary genetics of dengue virus. Infect Genet Evol. 2003;3(1):19-28.

58. Huang Y-LS, Higgs S, Horne KM, Vanlindingham DL. Flavivirus-mosquito interactions. Viruses. 2014;6:4703-30. 
59. Gaunt MW, Sall AA, de Lamballerie X, Falconar AKI, Dzhivanian TI, Gould EA. Phylogenetic relationships of flaviviruses correlate with their epidemiology, disease association and biogeography. J Gen Virol. 2001;82(8):1867-76.

60. Williams MC, Woodall JP. An epidemic of an illness resembling dengue in the Morogoro district of Tanganyika. East Afr Med J. 1964;41:271-5.

61. McIntosh BM, Dos Santos ISL, Meenahan GM. Culex (Eumelanomyia) rubinotus Theobald as vector of Banzi, Germiston and Witwatersrand viruses. J Med Entomol. 1976;12:645-6.

62. Jupp P. Mosquitoes of southern Africa: Culicinae and Toxorhynchitinae. Hartebeespoort, South Africa: Ekogilde Publishers; 1996.

63. McIntosh BM. Susceptibility of some African wild rodents to infection with various arthropod-borne viruses. Trans R Soc Trop Med Hyg. 1961;55:63-8.

64. Jupp PG, Mclntosh BM, Anderson D. Culex (Eumelanomyia) rubinotus Theobald as vector of Banzi, Germiston and Witwatersrand viruses IV: observations on the biology of C rubinotus. J Med Entomol. 1976;12:647-51.

65. Jupp PG. Chapter 6. Vectors: mosquitoes. In: JAW Coetzer JAW, Tustin RC, editors. Infectious diseases of livestock. 2nd ed. Cape Town: Oxford University Press; 2004.

66. Harrington LC, Fleisher A, Ruiz-Moreno D, Vermeylen F, Wa CV, Poulson RL, et al. Heterogeneous feeding patterns of the dengue vector, Aedes aegypti, on individual human hosts in rural Thailand. PLoS Negl Trop Dis. 2014;8(8):e3048.

67. Kraemer MUG, Sinka ME, Duda KA, Mylne A, Shearer FM, Brady OJ, et al. The global compendium of Aedes aegypti and Aedes albopictus occurrence. Sci Data. 2015;2:150035.

68. Semenza JC, Sudre B, Miniota J, Rossi M, Hu W, Kossowsky D, et al. International dispersal of dengue through air travel: importation risk for Europe. PLoS Negl Trop Dis. 2014:8:e3278.

69. Amarasinghe A, Kuritsky JN, Letson GW, Margolis HS. Dengue virus infection in Africa. Emerg Infect Dis. 2011;17(8):1349-54.

70. Wang E, Ni H, Xu R, Barrett AD, Watowich SJ, Gubler DJ, Weaver SC Evolutionary relationships of endemic/epidemic and sylvatic dengue viruses. J Virol. 2000;74:3227-34.

71. Conway MJ, Colpitts TM, Fikrig E. Role of the vector in arbovirus transmission. Annu Rev Virol. 2014;1:71-88.

72. Dhar-Chowdhury P, Haque CE, Lindsay R, Hossain S. Socioeconomic and ecological factors influencing Aedes aegypti prevalence, abundance, and distribution in Dhaka, Bangladesh. Am J Trop Med Hyg. 2016;94(6): 1223-33.

73. Guzman MG, Kouri G. Dengue: an update. Lancet Infect Dis. 2002;2:33-42.

74. Rigau-Perez JG, Clark GG, Gubler DJ, Sanders EJ, Vorndam AV. Dengue and dengue haemorrhagic fever. Lancet. 1998;352:971-7.

75. Gudo ES, Lesko B, Vene S, Lagerqvist N, Candido SI, de Deus NR, et al. Seroepidemiologic screening for zoonotic viral infections, Maputo, Mozambique. Emerg Infect Dis. 2016a;22(5):915-7.

76. Benedict MQ, Levine RS, Hawley WA, Lounibos LP. Spread of the Tiger: global risk of invasion by the mosquito Aedes albopictus. Vector Borne Zoonotic Dis. 2007;7(1):76.

77. Diallo M, Sall AA, Moncayo AC, Ba Y, Fernandez Z, Ortiz D, et al. Potential role of sylvatic and domestic African mosquito species in dengue emergence. Am J Trop Med Hyg. 2005;73(2):445-9.

78. Gratz NG. Critical review of the vector status of Aedes albopictus. Med Vet Entomol. 2004;18(3):215-27.

79. Dickson LB, Sanchez-Vargas I, Sylla M, Fleming K, Black WC IV. Vector competence in west African Aedes aegypti is Flavivirus species- and genotype-dependent. PLoS Negl Trop Dis. 2014;8(10):e3153.

80. Gubler DJ. Dengue and dengue hemorrhagic fever: its history and resurgence as a global public health problem. In: Gubler DJ, Kuno G, editors. Dengue and dengue hemorrhagic fever. New York: CAB International; 1997. p. 1-22

81. Smithburn KC, Haddow AJ. Ntaya virus. A hitherto unknown agent isolated from mosquitoes in Uganda. Proc Soc Exp Biol Med. 1951;77:130-3.

82. Antipa C, Girjabu E, Iftimovici R, Drăgănescu N. Serological investigations concerning the presence of antibodies to arboviruses in wild birds. Virologie. 1984;35(1):5-9.

83. Dilcher M, Sall AA, Hufert FT, Weidmann M. Full-length genome sequence of Ntaya virus. Virus Genes. 2013;46:162-4.

84. Davidson I. A new look at avian flaviviruses. Israel J Vet Med. 2015;70(2):3-8.

85. Kokernot RH, Smithburn KC, Muspratt J, Hodgson B. Studies on the arthropod-borne viruses of Tongaland. VIII. Spondweni virus, an agent previously unknown, isolated from Taeniorhunchus (Mansonioides) uniformis Theo. S Afr J Med Sci. 1957d;22:103-12.
86. Worth CB, Paterson HE, de Meillon B. The incidence of arthropod-borne viruses in a population of culicine mosquitoes in Tongaland, Union of South Africa (January, 1956, through April, 1960). Am J Soc Trop Med Hyg. 1961; 10(4):583-92.

87. Haddow AD, Woodall JP. Distinguishing between Zika and Spondweni viruses. Bull World Health Organ. 2016:94:711-711A.

88. Haddow AD, Nasar F, Guzman H, Ponlawat A, Jarman RG, Tesh RB, Weaver SC. Genetic characterization of Spondweni and Zika viruses and susceptibility of geographically distinct strains of Aedes aegypti, Aedes albopictus and Culex quinquefasciatus (Diptera: Culicidae) to Spondweni virus. PLoS Negl Trop Dis. 2016;10(10):e0005083.

89. Boorman JPT. Transmission of Uganda S virus by Aedes (Stegomyia) aegypti Linn. Trans R Soc Trop Med Hyg. 1958;52(4):383-8.

90. Engel D, Jöst H, Wink M, Börstler J, Bosch S, Garigliany M, et al. Reconstruction of the evolutionary history and dispersal of Usutu virus, a neglected emerging arbovirus in Europe and Africa. MBio. 2016;7(1):e01938-15.

91. Nikolay B, Diallo M, Boye CS, Sall AA. Usutu virus in Africa. Vector Borne Zoonotic Dis. 2011;11:1417-23.

92. Ashraf U, Ye J, Ruan X, Wan S, Zhu B, Cao S. Usutu virus: An emerging flavivirus in Europe. Viruses. 2015;7:219-38.

93. Ochieng C, Lutomiah J, Makio A, Koka H, Chepkorir E, Yalwala S, et al. Mosquito-borne arbovirus surveillance at selected sites in diverse ecological zones of Kenya; 2007-2012. Virol J. 2013;10:140.

94. Cavrini F, Gaibani P, Longo G, Pierro AM, Rossini G, Bonilauri P, et al. Usutu virus infection in a patient who underwent orthotropic liver transplantation, Italy, august-September 2009. Euro Surveill. 2009;14(5):19448.

95. Pecorari M, Longo G, Gennari W, Grottola A, Sabbatini A, Tagliazucchi S, et al. First human case of Usutu virus neuroinvasive infection, Italy, augustSeptember 2009. Euro Surveill. 2009;14(50):19446.

96. Nikolay B, Diallo M, Faye O, Boye CS, Sall AA. Vector competence of Culex neavel (Diptera: Culicidae) for Usutu virus. Am J Trop Med Hyg. 2012;86(6):993-6.

97. Cornet M, Robin Y, Chateau R, Heme G, Adam C, Valade M, et al. Isolementd'arbovirus au Senegal Oriental a partir de moustiques (19721977) et notes surl'epidemiologie des virus transmis par les Aedes en particulier du virus amaril. Cahiers ORSTOM Ser Entomologiemed Parasitol. 1979;17:149-63.

98. Cadar D, Becker N, RdM C, Borstler J, Jost H, Schmidt-Chanasit J. Usutu virus in bats, Germany, 2013. Emerg Infect Dis. 2014;20:1771-3.

99. Weiss KE, Haig DA, Alexander RA. Wesselsbron virus - a virus not previously described associated with abortion in domestic animals. Onderstepoort J Vet Res. 1956;27:183-95.

100. Kokernot RH, Smithburn KC, Paterson HE, De Meillon B. Further isolations of Wesselsbron virus from mosquitoes. SAMJ. 1960a:871-4.

101. Kokernot RH, Smithburn KC, Kluge E. Neutralizing antibodies against arthropod-borne viruses in the sera of domestic quadrupeds ranging in Tongaland, Union of South Africa. Ann Trop Med Parasitol. 1961b;55:73-85.

102. Smithburn KC, Hughes TP, Burke AW, Paul JH. A neurotropic virus isolated from the blood of a native of Uganda. Am J Trop Med. 1940;20:71-92.

103. Botha EM, Markotter W, Wolfaardt M, Paweska JT, Swanepoel R, Palacios G, et al. Genetic determinants of virulence in pathogenic lineage 2 West Nile virus strains. Emerg Infect Dis. 2008;14(2):222-30.

104. Chancey C, Grinev A, Volkova E, Rios M. The global ecology and epidemiology of West Nile virus. Biomed Res Int. 2015:2015:276230.

105. Gubler DJ. The continuing spread of West Nile virus in the western hemisphere. Clin Infect Dis. 2007:45(8):1039-46.

106. Venter M, Human S, Zaayman D, Gerdes GH, Williams J, Steyl J, et al. Lineage 2 West Nile virus as cause of fatal neurologic diseases in horses, South Africa. Emerg Infect Dis. 2009;15(6):877-84.

107. Fros JJ, Miesen P, Vogels CB, Gaibani P, Sambri V, Koenraadt CJ, et al. Comparative Usutu and West Nile virus transmission potential by local Culex pipiens mosquitoes in north-western Europe. One Health. 2015;1:31-6.

108. Engler O, Savini G, Papa A, Figuerola J, Groschup MH, Kampen H, et al. European surveillance for West Nile virus in mosquito populations. Int J Environ Res Public Health. 2013;10:4869-95.

109. Venter M, Human S, Van Niekerk S, Williams J, van Eeden C, Freeman F. Fatal neurologic disease and abortion in mare infected with lineage 1 West Nile virus, South Africa. Emerg Infect Dis. 2011;17(8):1534-6.

110. Burt FJ, Grobbelaar AA. Leman, Anthony FS, Gibson GVF, Swanepoel R. Phylogenetic relationships of southern African West Nile virus isolates. Emerg Infect Dis. 2002;8(8):820-6. 
111. Fall G, Faye M, Weidmann M, Kaiser M, Dupressoir A, Ndiaye EH, et al. Realtime RT-PCR assays for detection and genotyping of West Nile virus lineages circulating in Africa. Vector Borne Zoonotic Dis. 2016;16(12):781-9.

112. Hernandez-Triana LM, Jeffries $C L$, Mansfield KL, Carnell G, Fooks AR, Johnson N. Emergence of West Nile virus lineage 2 in Europe: a review on the introduction and spread of a mosquito-borne disease. Front Public Health. 2014;2:271.

113. Bondre VP, Jadi RS, Mishra AC, Yergolkar PN, Arankalle VA. West Nile isolates from India: evidence for a distinct genetic lineage. J Gen Virol. 2007;88(3):875-4.

114. Petersen LR, Brault AC, Nasci RS. West Nile virus: review of the literature JAMA. 2013;310:308-15.

115. Burt FL, Goedhals D, Mathengtheng L. Arboviruses in southern Africa: are we missing something? Future Virol. 2014;9(11):993-1008.

116. Venter M, Swanepoel R. West Nile virus lineage 2 as a cause of zoonotic neurological disease in humans and horses in southern Africa. Vector Borne Zoonotic Dis. 2010;10(7):659-64.

117. Cantile C, Di Guardo G, Eleni C, Arispici M. Clinical and neuropathological features of West Nile virus equine encephalomyelitis in Italy. Equine Vet J. 2000;32:32-5.

118. Murgue B, Murri S, Zientara S, Durand B, Durand JP, Zeller H. West Nile outbreak in horses in southern France, 2000: the return after 35 years. Emerg Infect Dis. 2001;7(4):692-6.

119. Garigliany MM, Marlier D, Tenner-Racz K, Eiden M, Cassart D, Gandar F, et al. Detection of Usutu virus in a bullfinch (Pyrrhula pyrrhula) and a great spotted woodpecker (Dendrocopos major) in north-west Europe. Vet J. 2014; 199(1):191-3.

120. Malkinson $M$, Banet $C$. The role of birds in the ecology of West Nile virus in Europe and Africa. Curr Top Microbiol Immunol. 2002;26:309-22.

121. Malkinson M, Banet C, Weisman Y, Pokamunski S, King R, Drouet MT, Deubel $\mathrm{V}$. Introduction of West Nile virus in the Middle East by migrating white storks. Emerg Infect Dis. 2002;8(4):392-7.

122. Marfin AA, Gubler DJ. West Nile encephalitis: an emerging disease in the United States. Clin Infect Dis. 2001;33:1713-9.

123. Petersen LR, Marfin AA. West Nile virus: a primer for the clinician. Ann Intern Med. 2002;137:173-9.

124. Rappole JH, Derrickson SR, Hubalek Z. Migratory birds and spread of West Nile virus in the western hemisphere. Emerg Infect Dis. 2000;6:319-28.

125. Vogels CBF, Mohlmann TWR, Melsen D, Favia G, Wennergren U, Koenraadt CJM. Latitudinal diversity of Culex pipiens biotypes and hybrids in farm, periurban, and wetland habitats in Europe. PLoS One. 2016;11(11):e0166959.

126. Andreadis TG. The contribution of Culex pipiens complex mosquitoes to transmission and persistence of West Nile virus in North America. J Am Mosq Control Assoc. 2012;28(4):137-51.

127. Kilpatrick AM, Kramer LD, Campbell S, Alleyne EO, Dobson AP, Daszak P. West Nile virus assessment and the bridge vector paradigm. Emerg Infect Dis. 2005;11:425-9

128. Jupp PG. The ecology of West Nile virus in South Africa and the occurrence of outbreaks in humans. Ann N Y Acad Sci. 2001;951:143-52.

129. Monath TP. Yellow fever. In: Monath TP, editor. The Arboviruses: epidemiology and ecology, Vol 5. Boca Raton, Fl: CRC Press; 1989. p. 139-231.

130. Mutebi J-P, Barrett ADT. The epidemiology of yellow fever in Africa. Microb Infect. 2002;4:1459-68.

131. Grobbelaar AA, Weyer J, Moolla N, van Vuren PJ, Moises F, Paweska JT. Resurgance of yellow fever in Angola, 2015-2016. Emerg Infect Dis. 2016; 22(10):1854-5.

132. Germain M, Cornet M, Mouchet J, Monath TP, Herve' JP, Salaun JJ, et al. Recent advances in research regarding sylvatic yellow fever in West and Central Africa. Bull Inst Pasteur 1982;80:315-330.

133. Haddow AJ, Smithburn KC, Dick GWA, Kitchen SF, Lumsden WHR. Implication of the mosquito Aedes (Stegomyia) africanus Theobald in the forest cycle of yellow fever in Uganda. Ann Trop Med Parasit. 1948;42(2):218-23.

134. Tomori O. Yellow fever: the recurring plague. Crit Rev Clin Lab Sci. 2004; 41(4):391-427.

135. Garske T, Van Kerkhove MD, Yactayo S, Ronveaux O, Lewis RF, Staples JE, et al, Yellow fever in Africa: estimating the burden of disease and impact of mass vaccination from outbreak and serological data. PLoS Med. 2014;11(5):e1001638.

136. Powell JR, Tabachnick WJ. History of domestication and spread of Aedes aegypti - a review. Mem Inst Oswaldo Cruz. 2013;108(Suppl. I):11-7.

137. Tabachnick WJ. Nature, nurture and evolution of intra-species variation in mosquito competence for arboviruses. Int J Environ Res Public Health. 2013;10:249-77.
138. Wasserman S, Tambyah PA, Lim PL. Yellow fever cases in Asia: primed for an epidemic. Int J Infect Dis. 2016;48:98-103.

139. Dick GW, Kitchen SF, Haddow AJ. Zika virus. 1. Isolations and serological specificity. Trans R Soc Trop Med Hyg. 1952;46:509-20.

140. Paixao ES, Barreto F, Teixeira Mda G, Mda C. History, epidemiology, and clinical manifestations of Zika: a systematic review. Am J Public Health. 2016;106:606-12.

141. Nutt C, Adams P. Zika in Africa - the invisible epidemic? Lancet. 2017;389:1595-6.

142. Centers for Disease Control and Prevention. Countries that have past or current evidence of Zika virus transmission (as of January 2016)., 2016. https://stacks.cdc.gov/view/cdc/37509. Accessed Feb 2017.

143. Gyawali N, Bradbury RS, Taylor-Robinson AW. The global spread of Zika virus: is public and media concern justified in regions currently unaffected? Infect Dis Poverty. 2016:5(1):37.

144. Faye O, Freire CC, lamarino A, Faye O, de Oliveira JVC, Diallo M, et al. Molecular evolution of Zika virus during its emergence in the 20th century. PLoS Negl Trop Dis. 2014;8:e2636.

145. Do Santos T, Rodriguez A, Almiron M, Sanhueza A, Ramon P, de Oliveira WK et al. Zika virus and the Guillain-Barré syndrome - case series from seven countries. N Engl J Med. 2016;375:1598-601.

146. Parra B, Lizarazo J, Jimenez-Arango JA, Zea-Vera AF, Gonzalez-Manrique G, Vargaz J, et al. Guillain-Barré syndrome associated with Zika virus infection in Colombia. N Engl J Med. 2016;375:1513-23.

147. Dodson BL, Rasgon JL. Vector competence of Anopheles and Culex mosquitoes for Zika virus. PeerJ. 2017;5:e3096

148. Heitmann A, Jansen S, Lühken R, Leggewie M, Badusche M, Pluskota B, et al. Experimental transmission of Zika virus by mosquitoes from central Europe. Euro Surveill. 2017;22(2):30437.

149. Huang Y-JS, Ayers VB, Lyons AC, Unlu I, Alto BW, Cohnstaedt LW, et al. Culex species mosquitoes and Zika virus. Vector Borne Zoonotic Dis. 2016;16(10):673-6.

150. Forrester NL, Palacios G, Tesh RB, Savji N, Guzman H, Sherman M, et al. Genome-scale phylogeny of the Alphavirus genus suggests a marine origin. J Virol. 2012;86(5):2729-38.

151. Powers AM, Brault AC, Tesh RB, Weaver SC. Re-emergence of chikungunya and o'nyong-nyong viruses: evidence for distinct geographical lineages and distant evolutionary relationships. J Gen Virol. 2000;81:471-9.

152. Enserink M. Chikungunya: no longer a third world disease. Science. 2007; 318:1860-1.

153. Tsetsarkin KA, Van Landingham DL, McGee CE, Higgs S. A single mutation in chikungunya virus affects vector specificity and epidemic potential. PLoS Pathog. 2007;3(12):e201.

154. Christian KA, luliano AD, Uyeki TM, Mintz ED, Nichol ST, Rollin P, et al. What are we watching - top global infectious disease threats, 2013-2016: an update from CDC's global disease detection operations center. Health Secur. 2017;15(5):1-10.

155. Centers for Disease Control \& Prevention. Where has chikungunya virus been found? April 22, 2016. https://www.cdc.gov/chikungunya/geo/index. html. Accessed June 2017.

156. I-Ching S, Kummerer BM, Yoke-Fun C, Roques P, Drosten C, AbuBakar S. Updates on chikungunya epidemiology, clinical disease, and diagnostics. Vector Borne Zoonotic Dis. 2015;15(4):223-30.

157. Weaver SC. Arrival of chikungunya virus in the new world: prospects for spread and impact on public health. PLoS Negl Trop Dis. 2014;8(6):e2921.

158. Coffey LL, Failloux A-B, Weaver SC. Chikungunya virus-vector interactions. Viruses. 2014:6(11):4628-63.

159. Charrel RN, de Lamballerie $X$, Raoult D. Chikungunya outbreaks - the globalization of vectorborne diseases. New Engl J Med. 2007;365(8):769-71.

160. Kokernot RH, De Meillon B, Paterson HE, Heymann CS, Smithburn KC. Middelburg virus: a hitherto unknown agent isolated from Aedes mosquitoes during an epizootic in sheep in the eastern Cape Province. $\mathrm{S}$ Afr J Med Sci. 1957a;22:145-53.

161. van Niekerk S, Human S, Williams J, van Wilpe E, Pretorius M, Swanepoel R, Venter M. Sindbis and Middelburg old world alphaviruses associated with neurologic disease in horses. South Africa Emerg Infect Dis. 2015;21(12):2225-9.

162. Attoui H, Sailleau C, Jaafar F, Belhouchet M, Biagini P, Cantaloube JF, et al. Complete nucleotide sequence of Middelburg virus, isolated from the spleen of a horse with severe clinical disease in Zimbabwe. J Gen Virol. 2007:88:3078-88.

163. van Eeden C. Investigation of viral causes of undiagnosed neurological disease in animals and their zoonotic risk to humans in South Africa. PhD thesis, Department of Medical Virology. South Africa: University of Pretoria; 2014. 
164. Hubálek Z, Rudolf I, Nowotny N. Arboviruses pathogenic for domestic and wild animals. Adv Virus Res. 2014:89:201-75.

165. Tricou V, Berthet N, Descorps-Declere S, Nakouné E, Kazanji M. Complete genome sequence of two Middelburg viruses isolated from arthropods in the Central African Republic. Genome Announc. 2014;2(5):e01078-14.

166. Lutomiah J, Omondi D, Masiga D, Collins M, Mureji PO, Ongus J, et al. Blood meal analysis and virus detection in blood-fed mosquitoes collected during the 2006-2007 Rift Valley fever outbreak in Kenya. Vector Borne Zoonotic Dis. 2014;14(9):656-64.

167. Haddow AJ, Davies CW, Walker AJ. O'nyong-nyong fever: an epidemic virus disease in East Africa. 1. Introduction. Trans R Soc Trop Med Hyg. 1960;54(6):517-22.

168. Lanciotti RS, Ludwig ML, Rwaguma EB, Lutwama JJ, Kram TM, Karabatsos N, et al. Emergence of epidemic o'nyong-nyong fever in Uganda after a 35-year absence: genetic characterization of the virus. Virology. 1998;252(1):258-68.

169. Lutwama JJ, Kayondo J, Savage HM, Burkot TR, Miller BR. Epidemic O'nyongnyong fever in southcentral Uganda, 1996-1997: entomologic studies in Bbaale Village, Rakai District. Am J Trop Med Hyg. 1999;61(1):158-62.

170. Smithburn KC, Haddow AJ. Semliki Forest virus. 1. Isolation and pathogenic properties. J Immunol. 1944;49(3):141-57.

171. Mclntosh BM, Worth CB, Kokernot RH. Isolation of Semliki Forest virus from Aedes (Aedimorphus) argenteopunctatus (Theobald) collected in Portuguese East Africa. Trans R Soc Trop Med Hyg. 1961b;55(2):192-8.

172. Taylor RM, Hurlbut HS, Work TH, Kingston JR, Frothingham TE. Sindbis virus: a newly recognized arthropod-transmitted virus. Am J Trop Med Hyg. 1955; 4:844-62.

173. Brown CR, O'Brien VA. Are wild birds important in the transport of arthropod-borne viruses? Ornithological monographs. 2011;71: vi + 64 pp.

174. Lwande OW, Obanda V, Bucht G, Mosomtai G, Otieno V, Ahim C, Evander M. Global emergence of alphaviruses that cause arthritis in humans. Infect Ecol Epidemiol. 2015;5:29853.

175. Brummer-Korvenkontio M, Saikku P. Mosquito-borne viruses in Finland. Med Biol. 1975;53:279-81

176. Brummer-Korvenkontio M, Vapalahti O, Kuusisto P, Saikku P, Manni T, Koskela P, et al. Epidemiology of Sindbis virus infections in Finland 1981-96: possible factors explaining a peculiar disease pattern. Epidemiol Infect. 2002; 129:335-45.

177. Kurkela S, Ratti O, Huhtamo E, Uzcategui NY, Nuorti JP, Laakkonen J, et al. Sindbis virus infection in resident birds, migratory birds, and humans. Finland Emerg Infect Dis. 2008;14(1):41-7.

178. Hesson JC, Lundstrom JO, Tok A, Ostman O, Lundkvist A. Temporal variation in Sindbis virus antibody prevalence in bird hosts in an endemic area in Sweden. PLoS One. 2016;11(8):e0162005.

179. Marklewitz M, Zirkel F, Kurth A, Drosten C, Junglen S. Evolutionary and phenotypic analysis of live virus isolates suggests arthropod origin of a pathogenic RNA virus family. Proc Natl Acad Sci USA. 2015;112(24):7536-41.

180. Briese T, Calisher $\mathrm{CH}$, Higgs S. Viruses of the family Bunyaviridae: are all available isolates reassortments? Virology. 2013:446:207-16.

181. Horne KM, Vanlandingham DL. Bunyavirus-vector interactions. Viruses. 2014; 6(11):4373-97.

182. Smithburn KC, Haddow AJ, Mahafft AF. A neurotropic virus isolated from Aedes mosquitoes caught in the Semliki Forest. Am J Trop Med Hyg. 1946; 26:189-208.

183. Kokernot RH, Heymann CS, Muspratt J, Wolstenholme B. Studies on arthropod-borne viruses of Tongaland. V. Isolation of Bunyamwera and Rift Valley fever viruses from mosquitoes. S Afr J Med Sci. 1957b;22:71-80.

184. Centres for Disease Control and Prevention. https://wwwn.cdc.gov/arbocat/ VirusDetails.aspx?ID=188\&SID=5. Accessed June 2017.

185. Digoutte JP, Salaun JJ, Robin Y, Bres P, Gagnard VJM. Les arboviruses mineures en Afrique Centrale et Occidentale. Medecine Tropicale. 1980;40:523-33.

186. Zeller HG, Diallo M, Angel G, Traoré-Lamizana M, Thonnon J, Digoutte JP. Ngari virus (Bunyaviridae: Bunyavirus). First isolation from humans in Senegal, new mosquito vectors, its epidemiology [in French]. Bull Soc Pathol Exot. 1996;89:12-6.

187. van Eeden C, Williams JH, Gerdes TGH, van Wilpe E, Vijoen A, Swanepoel R, Venter M. Shuni virus as cause of neurologic disease in horses. Emerg Infect Dis. 2012;18(2):318-21.

188. Golender N, Brenner J, Valdman M, Khinich E, Bumbarov V, Panshin A, et al. Malformations caused by Shuni virus in ruminants, Israel, 2014-15. Emerg Infect Dis. 2015;21(12):2267-8.
189. Daubney R, Hudson JR. Enzootic hepatitis or Rift Valley fever: an undescribed virus disease of sheep cattle and man from east Africa. J Path Bacteriol. 1931;34:545-79.

190. Centers for Disease Control and Prevention. Rift Valley Fever; 2017. https:// www.cdc.gov/vhf/rvf/outbreaks/distribution-map.html. Accessed June 2017.

191. Nakoune E, Kamgang B, Berthet N, Manikariza A, Kazanji M. Rift Valley fever virus circulating among ruminants, mosquitoes and humans in the Central African Republic. PLoS Negl Trop Dis. 2016;10(10):e0005082.

192. Sang R, Kioko E, Lutomiah J, Warigia M, Ochieng C, O'Guinn M, et al. Rift Valley fever virus epidemic in Kenya, 2006/2007: the entomologic investigations. Am J Trop Med Hyg. 2010;83(Suppl 2):28-37.

193. McIntosh BM, Jupp PG, Dos Santos I, Barnard BJH. Vector studies on Rift Valley fever virus in South Africa. S Afr Med J. 1980;58:127-32.

194. Linthicum KJ, Davies FG, Kairo A, Bailey CL. Rift Valley fever virus (family Bunyaviridae, genus Phlebovirus): isolations from Diptera collected during an inter-epizootic period in Kenya. J Hyg (Lond). 1985;95:197-209.

195. Anyamba A, Linthicum KJ, Small J, Britch SC, Pak E, de la Rocque S, et al. Prediction, assessment of the Rift Valley fever activity in east and southern Africa 2006-2008 and possible vector control strategies. Am J Trop Med Hyg. 2010;8(Suppl. 2):43-51.

196. Pedro SA, Abelman S, Tonnang HZ. Predicting Rift Valley fever interepidemic activities and outbreak patterns: insights from a stochastic hostvector model. PLoS Negl Trop Dis. 2016;10(12):e0005167.

197. Boongaarts J. Human population growth and the demographic transition. Phil Trans R Soc B. 2009;364:2985-90.

198. United Nations. World urbanization prospects: the 2014 revision, highlights. United Nations Department of Economic and Social Affairs, Populations Division. New York (ST/ESA/SER.A/352); 2014.

199. Soper L. Ventures in world health. Report number 355. Pan American health organization PAHO scientific publication. Washington, DC: Pan American Health Organization; 1977.

200. Tabachnick WJ. Evolutionary genetics of arthropod-borne diseases. The yellow fever mosquito. Am Entomol. 1991;37:14-24.

201. Grist NR. Aedes albopictus: the tyre-travelling tiger. J Inf Secur. 1993;27:1-4.

202. Jupp PG, Kemp A. Aedes albopictus and other mosquitoes imported in tires into Durban, South Africa. J Am Mosq Control Assoc. 1992;8(3):321-2.

203. Knudsen AB. Global distribution and continuing spread of Aedes albopictus. Parassitologia. 1995;37(2-3):91-7.

204. Reiter P. Aedes albopictus and the world trade in used tires, 1988-1995: the shape of things to come? J Am Mosq Control Assoc. 1998;14:83-94.

205. Reiter P, Sprenger D. The used tire trade: a mechanism for the worldwide dispersal of container breeding mosquitoes. J Am Mosq Control Assoc. 1987:3:494-501.

206. Kollars TM, Kollars PG, Hulsey B. Reducing the risk to marine ports from invasive mosquito species, zika, dengue, chikungunya viruses and filariasis. Int J Med. 2016;4(2):70-3.

207. Tatem AJ, Hay SI, Rogers DJ. Global traffic and disease vector dispersal. Proc Natl Acad Sci USA. 2006;103:6242-7.

208. United Nations. Sustained growth in international tourism despite challenges. United Nations World Tourism Organization, Press Release PR 17003. 17 January 2017.

209. World Trade Organization. Trade growth to remain subdued in 2016 as uncertainties weigh on global demand. World Trade Organization, Geneva, Switzerland. Press Release PRESS/768. April 2016.

210. IHS. Five trends shaping the maritime industry; 2017. https://www.ihs.com/ industry/maritime.html. Accessed June 2017.

211. Juliano SA, Lounibos LP. Ecology of invasive mosquitoes: effects on resident species and on human health. Ecol Lett. 2005;8:558-74.

212. Poulakou G, Plachouras D. Planet's population on the move, infections on the rise. Intensive Care Med. 2016:42(12):2055-8.

213. Pepin M, Bouloy M, Bird BH, Kemp A, Paweska J. Rift Valley fever virus (Bunyaviridae: Phlebovirus): an update on pathogenesis, molecular epidemiology, vectors, diagnostics and prevention. Vet Res. 2010:41(6):61.

214. Rosen L. Further observations on the mechanism of vertical transmission of flaviviruses by Aedes mosquitoes. Am J Trop Med Hyg. 1988;39(1):123-6.

215. Leake CJ. Arbovirus-mosquito interactions and vector specificity. Parasitol Today. 1992:8(4):123-8.

216. Gokhale MD, Barde PV, Sapkal GN, Gore MM, Mourya DT. Vertical transmission of Dengue-2 virus through Aedes albopictus mosquitoes. J Commun Dis. 2001;33:212-5. 
217. Angel B, Joshi V. Distribution and seasonality of vertically transmitted dengue viruses in Aedes mosquitoes in arid and semi-arid areas of Rajasthan, India. J Vector Borne Dis. 2008;45:56-9.

218. Martins VEP, Alencar CH, Kamimura MT, Araujo FMC, de Simone SG, Dutra RF, Guedes MIF. Occurrence of natural vertical transmission of dengue-2 and dengue-3 viruses in Aedes aegypti and Aedes albopictus in Fortaleza, Ceara, Brazil. PLoS One. 2012;7(7):e41386.

219. Aitken $T H$, Tesh RB, Beaty BJ, Rosen $L$. Transovarial transmission of yellow fever virus by mosquitoes (Aedes aegypti). Am J Trop Med Hyg. 1979;28(1):119-21.

220. Beaty BJ, Tesh RB, Aitken TH. Transovarial transmission of yellow fever virus in Stegomyia mosquitoes. Am J Trop Med Hyg. 1980;29(1):125-32.

221. Diallo M, Thonnon J, Fontenile D. Vertical transmission of the yellow fever virus by Aedes aegypti (Diptera, Culicidae): dynamics of infection in F1 adult progeny of orally infected females. Am J Trop Med Hyg. 2000;62(1):151-6.

222. Fontenille $D$, Diallo $M$, Mondo $M$, Ndiaye $M$, Thonnon J. First evidence of natural vertical transmission of yellow fever virus in Aedes aegypti, its epidemic vector. Trans R Soc Trop Med Hyg. 1997;91:533-5.

223. Nelms BM, Fechter-Legget E, Carroll BD, Macedo P, Kluh S, Reisen WK. Experimental and natural vertical transmission of West Nile virus by California Culex (Diptera: Culicidae) mosquitoes. J Med Entomol. 2013b;50(2):371-8.

224. Baqar S, Hayes CG, Murphy JR, Watts DM. Vertical transmission of West Nile virus by Culex and Aedes species mosquitoes. Am J Trop Med Hyg. 1993; 48(6):757-62.

225. De Souza M, Freier JE. Vertical transmission of dengue 1 virus by Haemagogus equinus mosquitoes. J Am Mosq Control Assoc. 1991;7(1):118-20.

226. Singh AK, Soni M, Agarwal A, Dash PK, Parida M, Gopalan N. Vertical transmission of Chikungunya virus in Aedes aegypti mosquitoes from northern India. Def Life Sci J. 2016;1(2):184-7.

227. Chompoosri J, Thavara U, Tawatsin A, Boonserm R, Phumee A, Sangkitporn $S$, Siriyasatien P. Vertical transmission of Indian Ocean lineage of chikungunya virus in Aedes aegypti and Aedes albopictus mosquitoes. Parasit Vectors. 2016;9:227.

228. Grunnill M, Boots M. How important is vertical transmission of dengue by mosquitoes (Diptera: Culicidae). J Med Ent. 2016;53(1):1-19.

229. Sota T, Mogi M. Interspecific variation in desiccation survival time of Aedes (Stegomyia) mosquito eggs is correlated with habitat and egg size. Oecologia. 1992;90:353-8.

230. Gubler DJ. Comparison of reproductive potentials of Aedes (Stegomyia) albopictus (Skuse) and Aedes (Stegomyia) polynesiensis marks. Mosq News. 1970;30:201-9.

231. Hien DS. Biology of Aedes aegypti (L., 1762) and Aedes albopictus (Skuse, 1895) (Diptera, Culicidae). 1. Resistance of eggs to low humidity. Acta Parasitol Pol. 1975;23:395-402.

232. Trpis M. Dry season survival of Aedes aegypti eggs in various breeding sites in the Dar es Salaam area. Tanzan Bull World Health Organ. 1972;47(3):433-7.

233. Trpis M. Ecological studies on the breeding of Aedes aegypti and other mosquitoes in shells of the giant African snail Achatina fulica. Bull World Health Organ. 1973;48(4):447-53.

234. Russell BM, Kay BH, Shipton W. Survival of Aedes aegypti (Diptera: Culicidae) eggs in surface and subterranean breeding sites during the northern Queensland dry season. J Med Entomol. 2001;38(3):441-5.

235. Fontenille D, Traore-Lamizana M, Diallo M, Thonnon J, Digoutte JP, Zeller HG. New vectors of Rift Valley fever in West Africa. Emerg Infect Dis. 1998; 4(2):289-93.

236. Elliott RM. Bunyaviruses and climate change. Clin Microbiol Infect. 2009;15: 510-7.

237. Sall AA, Zanotto PM, Sene OK, Zeller HG, Digoutte JP, Thiongane Y, Bouloy M. Genetic reassortment of Rift Valley fever virus in nature. J Virol. 1999;73:8196-200.

238. Pringle CR. Genetics and genome segment reassortment. In: Elliott RM, editor. The Bunyaviridae. New York: Plenum Press; 1996. p. 189-226.

239. Gould EA, Higgs S. Impact of climate change and other factors on emerging arbovirus diseases. Trans R Soc Trop Med Hyg. 2009;103:109-21.

240. Vazeille M, Moutailler S, Coudrier D, Rousseaux C, Khun H, Huerre M, et al. Two chikungunya isolates from the outbreak of La Reunion (Indian Ocean) exhibit different patterns of infection in the mosquito, Aedes albopictus. PLoS One. 2007:e1168.

241. Bonilauri P, Bellini R, Calzolari M, Angelini R, Venturi L, Fallacara F, et al. Chikungunya virus in Aedes albopictus, Italy. Emerg Infect Dis. 2008;14:852-4.
242. Brown JE, McBride CS, Johnson P, Ritchie S, Paupy C, Bossin H, et al Worldwide patterns of genetic differentiation imply multiple 'domestications' of Aedes aegypti, a major vector of human diseases. Proc Biol Sci. 2011;278:2446-54.

243. Moore M, Sylla M, Goss L, Burugu MW, Sang R, Kamau LW, et al. Dual African origins of global Aedes aegypti s.l. populations revealed by mitochondrial DNA. PLoS Negl Trop Dis. 2013;7(4):e2175.

244. Abilio AP, Kleinschmidt I, Rehman AM, Cuamba N, Ramdeen V, Mthembu DS, et al. The emergence of insecticide resistance in central Mozambique and potential threat to the successful indoor residual spraying malaria control programme. Malar J. 2011;10:110.

245. Hargreaves K, Koekemoer LL, Brooke BD, Hunt RH, Mthembu J, Coetzee M. Anopheles funestus resistant to pyrethroid insecticides in South Africa. Med Vet Entomol. 2000;14:181-9.

246. Nkya TE, Akhouayri I, Poupardin R, Batengana B, Mosha F, Magesa S, et al. Insecticide resistance mechanisms associated with different environments in the malaria vector Anopheles gambiae: a case study in Tanzania. Malar J. 2014;13:28.

247. Okoye PN, Brooke BD, Koekemoer LL, Hunt RH, Coetzee M. Characterisation of DDT, pyrethroid and carbamate resistance in Anopheles funestus from Obuasi, Ghana. Trans R Soc Trop Med Hyg. 2008;102(6):591-8.

248. Protopopoff N, Matowo J, Malima R, Kavishe R, Kaaya R, Wright A, et al. High level of resistance in the mosquito Anopheles gambiae to pyrethroid insecticides and reduced susceptibility to bendiocarb in north-western Tanzania. Malar J. 2013;12:149.

249. Ranson $H$, Jensen $B$, Vulule JM, Wang X, Hemingway J, Collins FH. Identification of a point mutation in the voltage-gated sodium channel gene of Kenyan Anopheles gambiae associated with resistance to DDT and pyrethroids. Insect Mol Biol. 2000;9(5):491-7.

250. Dusfour I, Thalmensy V, Gaborit P, Issaly J, Carinci R, Girod R. Multiple insecticide resistance in Aedes aegypti (Diptera: Culicidae) populations compromises the effectiveness of dengue vector control in French Guiana. Mem Inst Oswaldo Cruz. 2011:106(3):346-52

251. Ishak IH, Jaal Z, Ranson H, Wondji CS. Contrasting patterns of insecticide resistance and knockdown resistance $(k d r)$ in the dengue vectors Aedes aegypti and Aedes albopictus from Malaysia. Parasit Vectors. 2015:8:181.

252. Lima EP, Paiva MHS, de Araujo AP, da Silva EVG, de Oliveira LN, Santana $A E G$, et al. Insecticide resistance in Aedes aegypti populations from Ceará, Brazil. Parasit Vectors. 2011:4:5.

253. Marcombe S, Mathieu RB, Pocquet N, Riaz M-A, Poupardin R, Selior S, et al. Insecticide resistance in the dengue vector Aedes aegypti from Martinique: distribution, mechanisms and relations with environmental factors. PLoS One. 2012;7(2):e30989.

254. Vontas J, Kioulos E, Pavlidi N, Morou E. Della Torre a, Ranson H. Insecticide resistance in the major dengue vectors Aedes albopictus and Aedes aegypti. Pestic Biochem Physiol. 2012;104(2):126-31.

255. Marcombe S, Farajollahi A, Healy SP, Clark GG, Fonseca DM. Insecticide resistance status of United States populations of Aedes albopictus and mechanisms involved. PLoS One. 2014;9(7):e101992.

256. Brogdon WG, McAllister JC. Insecticide resistance and vector control. Emerg Infect Dis. 1998;4(4):605-13.

257. Norris LC, Norris DE. Insecticide resistance in Culex quinquefasciatus mosquitoes after the introduction of insecticide-treated bed nets in Macha. Zambia J Vector Ecol. 2011;36(2):411-20.

258. Yanola J, Chamnanya S, Lumjuan N, Somboon P. Insecticides resistance in the Culex quinquefasciatus populations from northern Thailand and possible resistance mechanisms. Acta Trop. 2015;149:232-8.

259. Intergovernmental Panel on Climate Change. Climate Change 2014 Synthesis Report. Contribution of Working Groups I, II and III to the Fifth Assessment Report of the Intergovernmental Panel on Climate Change. Geneva: IPCC; 2014. https://www.ipcc.ch/.

260. Vonesch N, D'Ovidio MC, Melis P, Remoli ME, Ciufolini MG, Tomao P, et al. Ann 1st Super Sanita. 2016;52(3):397-405.

261. Jia $P$, Chen $X$, Chen J, Lu L, Liu Q, Tan X. How does the dengue vector mosquito Aedes albopictus respond to global warming? Parasit Vectors. 2017:10:140.

262. Schaffner F, Hendrickx G, Scholte EJ, Medlock J, Angelini P, Ducheyne E. Development of Aedes albopictus risk maps. Stockholm: European Centre for Disease Prevention and Control; 2008. 
263. Sudeep AB, Bondre VP, Mavale MS, Ghodke YS, George RP, Aher RV, Gokhale MD. Preliminary findings on Bagaza virus (Flavivirus: Flaviviridae) growth kinetics, transmission potential \& transovarial transmission in three species of mosquitoes. Indian J Med Res. 2013;138(2):257-61.

264. McIntosh BM, Jupp PG, Dos Santos ISL, Meenehan GM. Culex (Eumelanomyia) rubinotus Theobald as vector of Banzi, Germiston and Witwatersrand viruses I. Isolation of virus from wild populations of $C$. rubinotus. J Med Entomol. 1976;12:637-40.

265. Wilkerson RC, Linton Y-M, Fonseca DM, Schultz TR, Price DC, Strickman DA. Making mosquito taxonomy useful: a stable classification of tribe aedini that balances utility with current knowledge of evolutionary relationships. PLoS One. 2015;10(7):e0133602.

266. Calisher $\mathrm{CH}$, Gould EA. Taxonomy of the virus family Flaviviridae. Adv Virus Res. 2003;59:1-19.

267. Robin Y, Cornet M, Le Gonidec G, Heme LG. Kedougou virus (Ar D14701): a new Arbovirus ("Flavivirus") isolated in Senegal. Ann Microbiol. 1978;129(2):239-44.

268. Kokernot RH, Smithburn KC, Weinbren MP, De Meillon B. Studies on arthropod-borne viruses of Tongaland. VI. Isolation of Pongola virus from Aedes (Banksinella) circumluteolus Theo. S Afr J Med Sci. 1957;22:81-92.

269. Williams MC, Simpson DI, Haddow AJ, Knight EM. The isolation of West Nile virus from man and of Usutu virus from the bird-biting mosquito Mansonia aurites (Theobald) in the Entebbe area of Uganda. Ann Trop Med Parasitol. 1964:68:367-74.

270. Vazquez A, Jimenez-Clavero M, Franco L, Donoso-Mantke O, Sambri V, Niedrig $\mathrm{M}$, et al. Usutu virus: potential risk of human disease in Europe. Euro Surveill. 2011;16(31):19935.

271. Lecollinet S, Blanchard Y, Manson C, Lowenski S, Laloy E, Quenault H, et al. Dual emergence of Usutu virus in common blackbirds, eastern France, 2015. Emerg Infect Dis. 2016;22(12):2225.

272. Williams RAJ, Vazquez A, Asante I, Bonney K, Odoom S, Puplampu N, et al. Yaounde-like virus in resident wild bird, Ghana. Afr J Microbiol Res. 2012; 6(9):1966-9.

273. Tukei PM, McCrae AWR. Natural history of yellow fever vectors and reservoirs: studies in East Africa. Cah ORSTOM Ser Ent Med et Parasitol. 1972; 10(2):159-61.

274. Monath TP. Yellow fever. In: Service MW, editor. The encyclopedia of arthropod-transmitted infections. Wallingford, UK: CAB International; 2001. p. $571-7$.

275. Gudo ES, Black JFP, Cliff JL. Chikungunya in Mozambique: a forgotten history. PLoS Negl Trop Dis. 2016c;10(11):e0005001.

276. McIntosh BM. Rift Valley fever. 1. Vector studies in the field. J S Afr Vet Med Assoc. 1972:43(4):391-5.

277. Berthet N, Nakoune E, Gessain A, Manuguerra JC, Kasanji M. Complete genome characterization of the Arumowot virus (unclassified Phlebovirus) isolated from Turdus libonyanus birds in the Central African Republic. Vector Borne Zoonotic Dis. 2016;16(2):139-43.

278. Mahy BWJ. The dictionary of virology. 4th ed. Burlington: Elsevier; 2009.

279. Pachler K, Ruzek D, Nowotny N. Molecular characterization of the African orthobunyavirus Ilesha virus. Infect Genet Evol. 2013;20:124-30.

280. Groseth A, Weisend C, Ebihara H. Complete genome sequencing of mosquito and human isolates of Ngari virus. Virol. 2012;86(24):13846-7.

281. Digoutte JP, Gagnard VJ, Bres P, Pajot FX. Nyando virus infection in man. Bull Soc Pathol Exot Filiales. 1972;65:751-8.

282. Williams MC, Woodall JP, Corbet PS. Nyando virus: a hitherto undescribed virus isolated from Anopheles funestus Giles collected in Kenya. Arch Gesamte Virusforsch. 1965;15:422-7.

283. Tchetgna HDS, Nakoune E, Selekon B, Gessain A, Manuguarra JC, Kazanji M, Berthet N. Molecular characterization of the Kamese virus, an unassigned rhabdovirus, isolated from Culex pruina in the Central African Republic. Vector Borne Zoonotic Dis. 2017:17(6):447-51.

284. Centres for Disease Control and Prevention. Kamese Virus. https://wwwn. cdc.gov/arbocat/VirusDetails.aspx?ID=223\&SID=7. Accessed June 2017.

285. Kokernot RH, McIntosh BM, Worth CB, De Souza J. Isolation of viruses from mosquitoes at Lumbo, Mozambique. II. Mossuril virus, a new virus isolated from the Culex (Culex) sitiens Wiedemann group. Am I Trop Med Hyg. 1962c;11(5):683-4.

\section{Submit your next manuscript to BioMed Central and we will help you at every step:}

- We accept pre-submission inquiries

- Our selector tool helps you to find the most relevant journal

- We provide round the clock customer support

- Convenient online submission

- Thorough peer review

- Inclusion in PubMed and all major indexing services

- Maximum visibility for your research

Submit your manuscript at www.biomedcentral.com/submit

) Biomed Central 